\title{
DEVELOPING A COLLECTION POLICY: PHOTOGRAPHIC AND DIGITAL ARCHIVES AT THE NATIONAL LIBRARY IN CHILE
}

by

Soledad Abarca de la Fuente

Bachelor of Fine Arts in Art with a minor in Restoration

Pontificia Universidad Católica de Chile, Santiago, 1996

\author{
A thesis \\ presented to Ryerson University in Toronto, Ontario \\ and George Eastman House in Rochester, New York \\ in partial fulfillment of the \\ requirements for the degree of \\ Master of Arts \\ in the Program of
}

Photographic Preservation and Collections Management

Toronto, Ontario, Canada, 2008

C) Soledad Abarca de la Fuente 2008 


\section{AUTHOR'S DECLARATION}

I hereby declare that I am the sole author of this thesis project. I authorize Ryerson University and George Eastman House, International Museum of Photography and Film, to lend this thesis to other institutions or individuals for the purpose of scholarly research.

I further authorize Ryerson University and George Eastman House, International Museum of Photography and Film, to reproduce this thesis by photocopying or by other means, in total or in part, at the request of other institutions or individuals for the purpose of scholarly research. 
DEVELOPING A COLLECTION POLICY: PHOTOGRAPHIC AND DIGITAL

\title{
ARCHIVES AT THE NATIONAL LIBRARY IN CHILE
}

Master of Arts, 2008

Soledad Abarca de la Fuente

Photographic Preservation and Collections Management

Ryerson University and George Eastman House

\begin{abstract}
The purpose of this thesis is to propose a model for a collections policy for the Photographic and Digital Archives of the National Library in Chile. The current policy is in its early stages of development and the institution has a large interest in its implementation.

The main focus of this research is collections policies, as a form of generating best practice in the field, and a vehicle to implement institutional mission, vision, and objectives from a theoretical and practical perspective.
\end{abstract}




\section{ACKNOWLEDGEMENTS}

My list of acknowledgements lengthy; my experience in this program would not have been possible without the valuable help of many people.

I would like to extend my gratitude to the faculty at Ryerson University and the staff at George Eastman House for sharing their knowledge and passion for photography with us, at the same time as giving me the chance of fulfilling the requirements while I was taking over a new position in the National Library of my country, Chile.

To my classmates, for all their friendship and support whenever I needed them. In particular, I would like to thank Marilia Fernandes, my Latin American companion, who I hope to be working together with very soon in our part of the world.

To Mary Proulx, for being such a good friend and making me feel so at home in Toronto, also my Ryerson teacher Valerie Kaelin for all her support and special friendship, and Sharan Gunning who helped me when I needed it most.

I would like to make a special mention of Howard and Carole Tanembaum, whose generous support helped me to accomplish my dream.

To Susan Patrick, for giving me the opportunity to work at the Special Collections Department at Ryerson Library, and to Rachel Stuhlman for hiring me at the Richard and Ronay Menschel Library at George Eastman House. Both work opportunities allowed me to stay in the Program and taught me a great deal about those unique photography book collections.

Thanks also to Fondart of Consejo Nacional de la Cultura y las Artes of Chile, whose funding allowed me to complete the second year of the PPCM program. 
I would also like to acknowledge the generous help of my thesis editor Jane Anderson, who assisted me in this difficult task, as well as my thesis advisor Don Snyder for guiding me through the stages of this thesis and for his patience working online.

To all collections managers and curators who contributed with me, answering the survey and sharing their valuable experience and sending me helpful documents.

And lastly, thank you to my parents Luis and Patricia for always believing in me, the too my dearest sister Patty and brother Pablo for being my inspiration. 


\section{DEDICATION}

This thesis is dedicated to my beloved husband Moisés, for all his love, incredible patience and permanent support. 


\section{TABLE OF CONTENTS}

AUTHOR'S DECLARATION ..........................................................................................

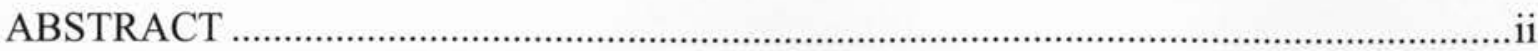

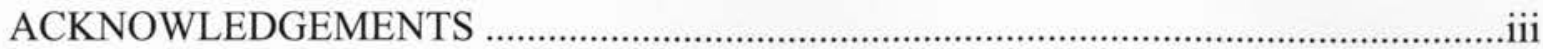

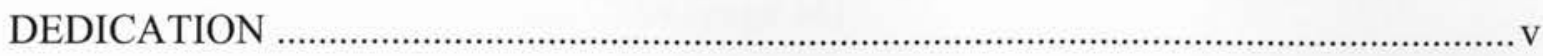

LIST OF ILLUSTRATIONS AND FIGURES ................................................................... vii

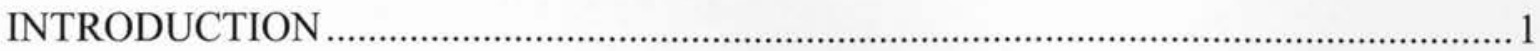

1 COLLECTIONS POLICIES, AN INSTITUTIONAL NEED .................................... 4

1.1 Collections Policy Definitions: International Documents ............................... 5

1.2 General bibliographic review ....................................................................... 6

1.3 Photographic Collections within National Libraries .......................................... 7

1.4 Photographic collections in Chile ................................................................. 8

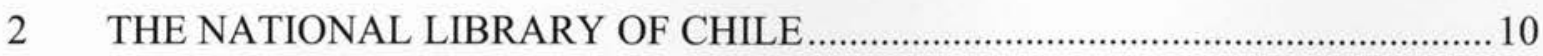

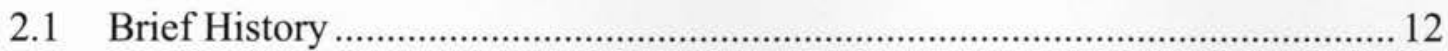

2.2 Mission and Vision ..................................................................................... 15

2.3 Policies at the National Library ...................................................................... 16

3 PHOTOGRAPHIC AND DIGITAL ARCHIVES OF THE NATIONAL

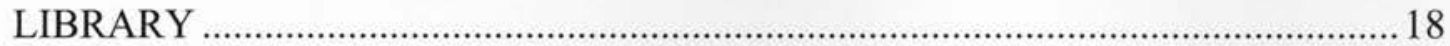

3.1 History and current activities................................................................... 19

3.2 Current Written Policy, a Critical Review....................................................... 23

4 COLLECTION POLICY PROPOSAL METHODOLOGY AND PRINCIPLES .....25

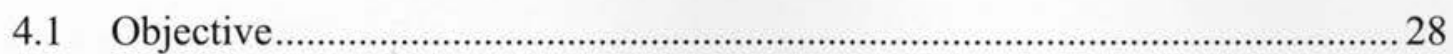

4.2 Description of the main topics included .......................................................... 28

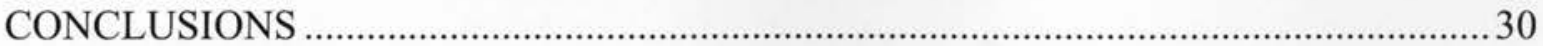

APPENDIX 1: PHOTOGRAPHIC AND DIGITAL ARCHIVES (PDA) ...........................33

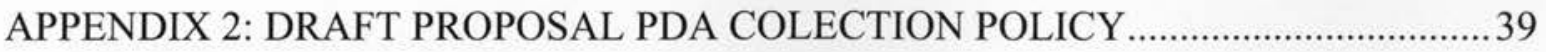

APPENDIX 3: CURRENT COLLECTION DEVELOPMENT POLICY..........................48

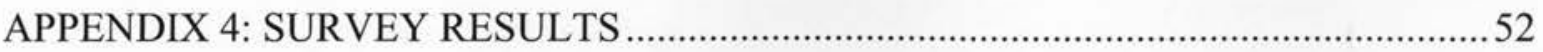

APPENDIX 5: QUICK COLLECTING GUIDE FOR CHILEAN PHOTOGRAPHY

OF TH 20TH CENTURY ....................................................................................... 72

APPENDIX 6: OFFICIAL SPANISH INSTITUTIONAL NAMES LIST....................... 75

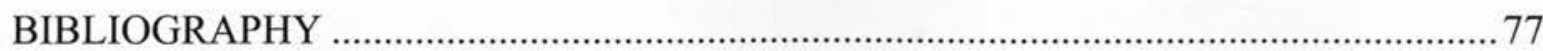




\section{LIST OF ILLUSTRATIONS AND FIGURES}

\section{Main text:}

1. Chart: DIBAM Organizational Chart (page 14)

2. Photo: National library, 1925 (page 15).

3. Chart: National library Organizational Chart (page 17)

4. Chart: PDA Collections Organization Chart (page 23)

5. Photo: PDA storage room

6. Photo: Screen of PDA online catalogue, available at www.bncatalogo.cl

\section{Appendix 1:}

1. National Library 1925

2. National library 2008

3. Medina Room

4. Gabriela Mistral Reading Room

5. National library Website, Home Page

6. Valparaiso, LeBlanc Studio, ca. 1860

7. Pablo Neruda, Hans Ehrmann 
8. Pablo Burchard, Hans Ehrmann

9. Marine, Jorge Opazo

10. Valparaíso Harbour Front, N.d.

11. Worker, Antonio Quintana, ca. 1960

12. Santiago Main Square, N.d.

13. Santiago, Jorge Opazo, ca. 1950

14. Santiago, N.d.

15. AFD Storage room

16. AFD Housing System

17. AFD working Area

18. AFD Furniture

19. AFD activities: Digitization

20. AFD activities: Digitization

21. AFD activities: Handling

22. AFD activities: Cataloguing

23. AFD activities: Cataloguing 


\section{INTRODUCTION}

Collection policies are fundamental instruments for collections management and institutional development. It is also a fascinating working area because, despite their importance, there are many cultural institutions where the lack of any body of written statements has caused poor decision making and major problems with their collections. Clear policies and procedures enable cultural institutions to develop best practices and to fulfill their social responsibility in their respective communities.

Photographic collections are constituents of a number of cultural institutions such as libraries, archives, and documentation centres, each with its own unique mission statement, objectives, and activities. The purpose of this research project was to develop a body of collection policies for the Photographic and Digital Archives at the National Library of Chile, primarily as a contribution to the collections management of the department, and also as a prototype that can be used to create the National Library's own body of written policies in the future.

The Photographic and Digital Archives is a relatively new department of the National Library. Since its creation in 1997 , the collection has been growing rapidly as a result of active collecting, including donation campaigns, purchases, and inter-institutional transfers. However, its current collection policy is in the early stages of development and has no procedures for activities carried out by the archives.

In addition, since 2001 with the creation of the website Memoria Chilena, ${ }^{l}$ the department has taken the initiative of digitizing thousands of bibliographic materials, as 
well as storing and preserving digitally the newly generated data, at the same time as giving public access to the assets. This project has generated new problems and increased the need for standards regarding the different objects preserved in the archives.

As previously mentioned, the overall lack of written policies at the National Library of Chile makes the task more difficult since there are many unsolved problems and inconsistent practices and criteria in every department of the institution, which frequently creates internal and external conflicts. As will be discussed later, this situation is very common in other Chilean and Latin American libraries and museums.

In this context, the main focus of this research was collection policies as a form of generating best practice in the field and as a vehicle to implement institutional mission, vision, and objectives from a theoretical and practical perspective. This includes the review of experiences of other photographic archives within libraries throughout the world, comparing realities of large institutions such as the Library of Congress and National Library of Australia, in contrast with other Latin American national libraries such as those of Colombia and Venezuela.

The research covers three main topics: the study of international documents and bibliography; a description of the case of study, which is the National Library of Chile's Photographic and Digital Archives, its history and current activities, and a critical review of its current written policies; and a review of policies of photographic collections within other libraries.

The policy draft has been written in an attempt to create a straightforward and wellarticulated document, to avoid misinterpretation, and especially to give guidelines for 
activities such as collecting, preserving, and research in accordance with the Photographic and Digital Archives mission statement. It is divided into five main sections: acquisitions, loans, and disposals; accountability, documentation, and inventory; conservation and preservation; storage security and movement; and access and use of collections.

The proposal also includes a dissemination and internal communications strategy of the policy within the National Library and a "quick collecting guide" for Chilean photography, with emphasis on the most important photographers, art movements, and time periods that are likely to be part of the collection.

Being a collections manager and working in a large public institution represents a major challenge to any professional. I believe that the implementation of these collection policies is the first step towards the consolidation of one of the most valuable photographic collections of Chile. 
"The library's primary task is to select, maintain, and provide access to relevant and representative information resources. Due to technological developments, libraries are, in the main, moving from holdings ('just in case') to access ('just in time') strategies."

Throughout the Photographic Preservation and Collections Management program, there have been several instances of the study of collection policies as instruments that facilitate the work of photographic collections within an institutional context. In fact, collections management and policymaking are two activities that work together because of the public commitment of museums, libraries, and archives to their own communities.

The first impression after reviewing a collection policies bibliography is that this is a basic requirement for any institution to improve their collections management activities; there is a general lack of collections policies among cultural institutions in Chile.

In this context, collections policies are a form of generating best practice in the field and a vehicle to implement institutional mission, vision, and objectives from a theoretical and practical perspective. “...[I]t is essential to recognize that an understanding of the principles of collections management is critical to the development of good practice."”3

\footnotetext{
2 Ifla, Guidelines for a Collection Development Policy Using the Conspectus Model. Available at: http://www.ifla.org/VII/s14/ndl/gcdp-e.pdf.

Fahy, Anne, editor. Collections Management. (London: Routledge, 1995), 2
} 
The Photographic and Digital Archives is an archive within a library, and sometimes this situation creates problems because of the self-evident fact that "photographs are not books" and, subsequently, they need to be treated differently, from their physical arrangement and conservation needs, to the documentation of their materiality, to their image content description. This reality is a shared problem within other libraries that were studied during this research.

Unfortunately, there is a lack of bibliography regarding this topic in Spanish, which makes this study even more relevant because this paper will be translated later as part of the activities involved in application of the policy, institutional approval, and dissemination ${ }^{4}$.

\subsection{COLLECTIONS POLICY DEFINITIONS: INTERNATIONAL DOCUMENTS}

As the study case is a national library, the first international organization reviewed is the International Federation of Library Associations (IFLA), which has many useful documents on its website regarding standards, ethics, preservation, and other topics providing guidelines for the member institutions. One example of this is Guidelines for a Collection Development Policy Using the Conspectus Model, which presents a concise and easy-to-follow guide to drafting policy documents.

${ }^{4}$ This thesis will be translated into Spanish and will be available online at the Photographic and Digital Archives of the National Library Website at the end of 2008. Additionally the Policy Proposal will be presented to the Chilean Photographic Archives community during a lecture in October as part of the activities for disseminating the author's experience at the Photographic Preservation and Collections Management Masters Program, which were funded partially by the Chilean Government. 
Another source of information is available from the International Council of Museums, which provides a framework and a code of ethics that are useful for their member institutions and are also applicable to other types of institutions with collections, such as libraries and archives.

Cooperative organizations dedicated to preservation and access of information such as the European Commission of Preservation and Access (Ecpa) ${ }^{5}$ and the Council on Library and Information Resources (Clir) are remarkable resources for policymaking as well as providing standards and updated information.

Ultimately, some prestigious university libraries such as those at Cornell and Harvard have also developed and shared information about collections care and policies.

Despite the diverse resources described, most documents agree on a simple definition of collections policy: “... a policy statement is a kind of framework and set of parameters within which staff and users work."

\subsection{GENERAL BIBLIOGRAPHIC REVIEW}

Collections policies information exists in several fields, though it is more common to find literature and manuals referring to museums rather than libraries and archives. But upon reading the material, we find that most aspects are the same, especially those texts that give guidelines to drafting the policies; in many cases, even the section heads are the

5 Unfortunately, Ecpa ended its activities in 2008, but they still have a great amount of useful information on their website, including the Sepia Project which is entirely devoted to photographic collections.

6 Ifla, Ibid. 
same. Another aspect is that there is more bibliographic material about policies in general than policies for specific departments or collections. For this study, in an attempt to address this gap, a survey method was used to contact collections managers directly.

There are many types of policies; one is the collections development policy, ${ }^{7}$ which is the written statement of an institution's intention for building collections. Other common policies are concerned with acquisition, preservation, and access to collections. Most institutions have a general policy that includes all aspects, and every collection department works within the same orientation and structure but in a detailed and specific way.

In summary, the main two focuses of a collections policy document are on:

- "Policies that explain why the collection exists and what will be in it. A policy tends to address ideals and generalities." ${ }^{8}$ It is a published document and, in most cases, is available on the website of the institution.

- "Procedures that explain how the policy will be implemented and who will be involved with the implementation. A procedure should be concrete and specific."9 Usually, it is a document for internal use and is not published.

\subsection{PHOTOGRAPHIC COLLECTIONS WITHIN NATIONAL LIBRARIES}

This review is dedicated to studying the reality of photographic collections within national libraries throughout the world, primarily by viewing their websites and contacting

\footnotetext{
7 "A collection development policy is a written statement of your library's intentions for building its collection. Available at: http://www.lib.az.us/cdt/colldev.aspx

8 The School Library Media Specialist Information Access \& Delivery: Policies and Procedures Available at: http://eduscapes.com/sms/access/policies.html

$9 \quad$ Ibid.
} 
selected institutions via e-mail to gather specific information through a survey questionnaire.

This review included the Library of Congress, National Library of Australia, National Library of New Zealand, and Libraries and Archives Canada in the Englishspeaking countries; as well as Latin American national libraries such as those of Colombia, Venezuela, Argentina, Uruguay, and Peru.

The first group, consisting of English-speaking national libraries, have their policies available online on a page dedicated to this subject. On the contrary, most of the Latin American institutions do not have written policies or they are works in progress, for example, Uruguay, Colombia, and the case of this study, Chile.

\subsection{PHOTOGRAPHIC COLLECTIONS IN CHILE}

The National Historical Museum [in Spanish, my translation] was the first photographic collection within a public cultural institution in Chile to be organized and preserved according to conservation standards. Created in 1978 with the organization of 2,000 original prints, today it has over a million photographic objects in all formats and processes, including cased photographs, prints, and negatives from 1840 to date, and has become the most valuable collection of $19^{\text {th }}$ century materials in the country. Today 300,000 photographs are available to the general public in the various printed and automatic catalogues and 20,000 images are available online at www.fotografiapatrimonial.cl. In 1999, as a result of a national survey of photographic 
collections that was carried out by the National Centre of Photographic Heritage, ${ }^{10}$ ninetythree collections were identified throughout Chile, most of them not organized or preserved at that time. ${ }^{11}$ After several initiatives were undertaken by this institution, at least thirty collections were properly stored and catalogued in local electronic databases.

Other important collections pertaining to the Directorate of Libraries, Archives and Museums (DIBAM) ${ }^{12}$ are those located in regional (e.g., Antofagasta, Copiapó, La Serena, Valparaíso, Easter Island, Talca, Concepción, Punta Arenas) and in specialized museums (Education, National History), which are commonly small in size, but very significant to their communities.

Additionally, the National Archives has a collection of numerous documentary photographs from the political newspaper Fortín Mapocho, as well as collections provided by the government of the most relevant records of the president's activities, termed the "Presidential Collection."

Public art museums in Chile have few photographic materials, due to the lack of photographers working in the fine arts and to insufficient financial resources required to acquire this type of material in Chilean museums and libraries.

In all of these cases, there is a deficiency of written policies dedicated to photographic collections, although both the National Historical Museum and National Library photographic archives are working on this important endeavour at the present time.

\footnotetext{
10 [In Spanish, my translation] Centro Nacional del Patrimonio Fotográfico. Available at: www.patrimoniofotografico.cl [From here See appendix 6: Official Spanish Institutional Names List] $11 \quad$ Centro Nacional del Patrimonio Fotográfico. Catastro Nacional de Colecciones Fotográficas Patrimoniales. (Santiago: N.e., 2000)[Unpublished].

12 [In Spanish, my translation] Dirección de Bibliotecas, Archivos y Museos (DIBAM). Available at: www.dibam.cl.
} 
THE NATIONAL LIBRARY OF CHILE

One of the key issues to understanding the complexity of policy making at the Photographic and Digital Archives is to examine the institutional context in which it exists, because there are many cultural aspects related to the history and nature of this type of public institution's administration.

The National Library (NL) is one of the oldest public institutions in Chile. Founded on August 19, 1813, it has been intimately connected with the cultural development of the country and its history. Over the years, the NL has evolved into the most important bibliographic centre of the country, providing services to thousands of people every day and preserving important heritage collections such as rare books, newspapers, magazines and periodicals, national and international literature, photography, cartography, manuscripts, music, and audiovisual media.

One of the goals of the NL is to keep up to date with new information technologies to help improve its services and create new ways to access its collections. Since 2000, the NL has been working on digitization projects and creating content websites, uploading digital resources to connect people with Chilean cultural heritage in order to contribute to the identity and values of the country: www.memoriachilena.cl and www.chileparaniños.cl are the best examples of these efforts.

Since 1929, the NL has reported directly to DIBAM, which today is under the administration of the Ministry of Education. DIBAM is a national entity that coordinates numerous institutions dedicated to working with the natural and cultural heritage; its structure comprises four hundred and fifteen local public libraries, twenty-three museums, 
and three regional archives, in addition to four national museums, the National Archives, the NL, and other technical divisions such as the Conservation Centre and the Intellectual Property Office. This complex and vast organization is observable in the following organizational chart:

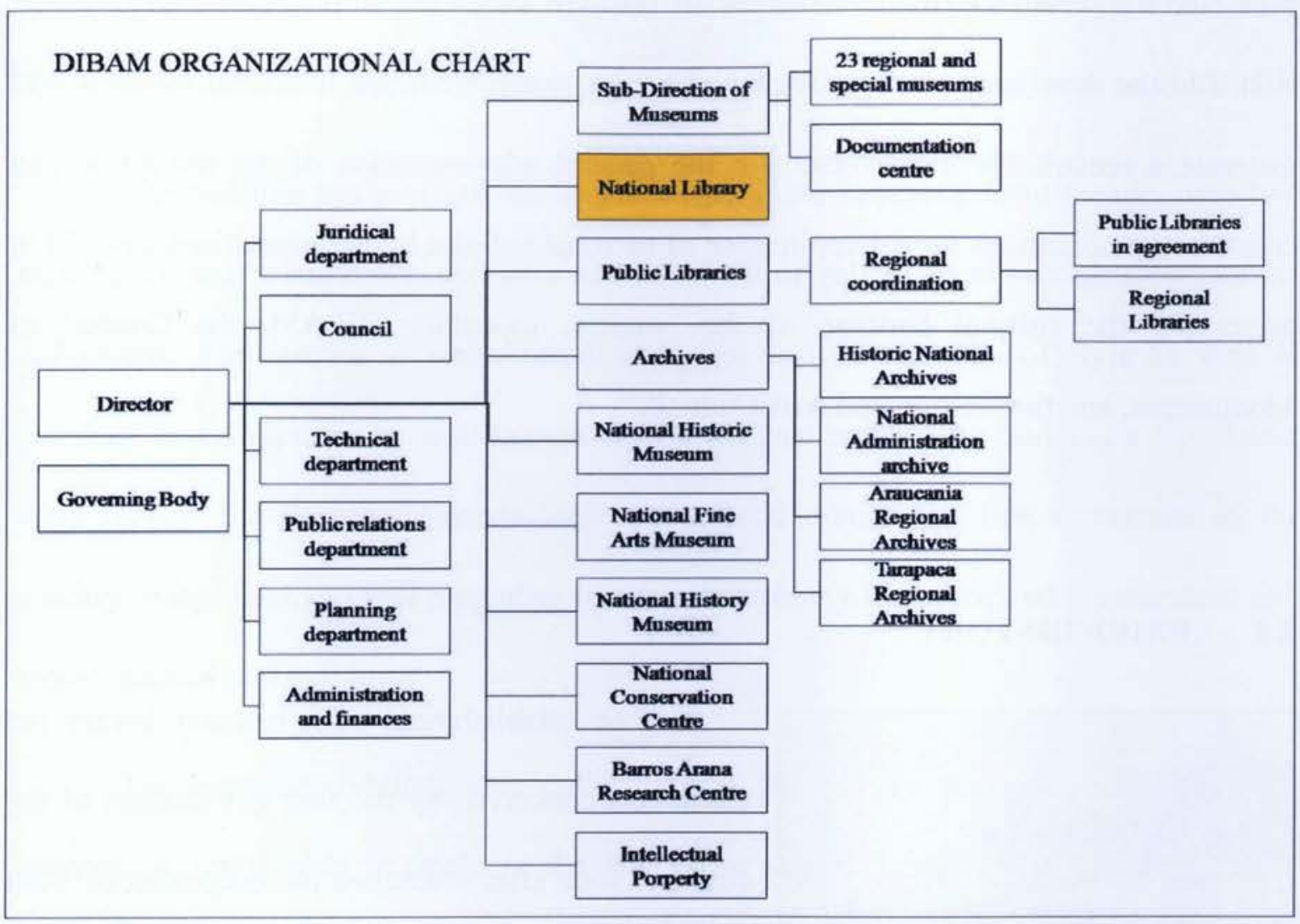

This organizational framework determines the actions and scope of the institution, influencing particularly the management and fundraising strategies of each department and local institution. Every administrational detail needs to be carried out according to the central government's planning and evaluation guidelines in an attempt to demonstrate effectiveness and transparency to the community. 
Another significant drawback of DIBAM is that several directive positions are elected by each new government (usually every four years), which sometimes creates problems of continuity in the development of long-term programs; for this reason, written policies are essential to ensure the stability of the institution in the eyes of the community.

On an optimistic note, the current government of President Michelle Bachellet has promoted the creation of a new structure for DIBAM called the Heritage Institute, ${ }^{13}$ which is still in the development stage. As far as has been revealed, this new configuration will generate a remarkable improvement in the general administration of the institution and create better conditions for the application of national policies by the institutions devoted to preserving the cultural heritage of the country, including DIBAM, the Council of Monuments, and the Culture and Arts Council..$^{14}$

\subsection{BRIEF HISTORY}

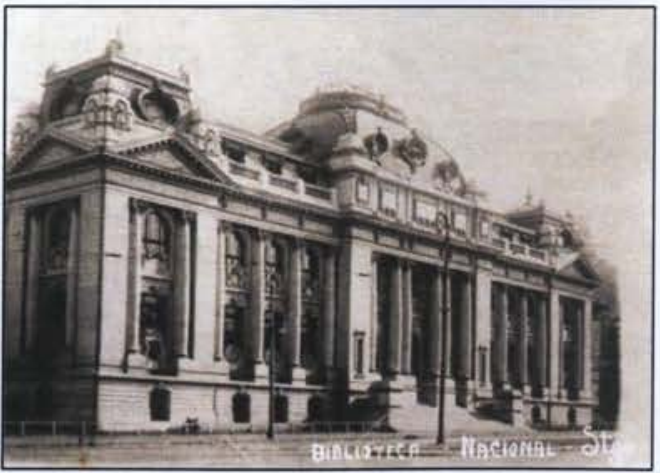

National Library, 1925 (Courtesy of PDA)

The establishment of a national library for Chile was conceived by the first government of the country, soon after it reached its independence from Spain in 1810. The NL first opened in 1813 in the Royal Customs Palace, and its founding directors were Manuel de Salas, Camilo Henríquez, and Manuel José Gandarillas, all prominent intellectual figures of their time. Successively, in

\footnotetext{
13 [In Spanish my translation] Instituto del Patrimonio.

14 Available at:

http://www.dibam.cl/contenido.asp?id contenido=824\&id_subsubmenu=1126\&id_submenu=1122\&id menu $=1$
} 
1843 and 1866 , the NL was moved to other locations due to lack of space because of the rapid increase in the size of its collections.

Ultimately, the construction of a special building was proposed in a downtown area of Santiago, located in the main block besides the Santa Lucía Hill. The construction of the central building started in 1914 and opened partially in 1927; however, the other galleries were finally completed in 1963 . The National Archives building is also located in the same block, which creates a central focus for cultural heritage in an important location in the city.

The building has a classic cross-shaped plan and imposing front façade, with two main levels and a basement, and nine central levels of galleries and storage areas for the collections. The interior is embellished with fine crafted elements of style as well as paintings and sculptures by well-known classic national artists. The building's Neoclassic style reflects the French influence that was a trend around the first centennial of the country, when Santiago was preparing for its celebration with a renewed urbanization and iconic institutional buildings.

The extensive bibliographic collections of the NL are the most valuable in the country. A remarkable example is the Biblioteca Americana, donated by the eminent bibliophile José Toribio Medina, which is one of the rarest in Latin America because it contains a complete selection of American Incunabula and over 33,000 titles from the $16^{\text {th }}$ to the $19^{\text {th }}$ centuries as well as 11,992 valuable manuscripts, maps, and photographs. ${ }^{15}$

15 This group of photographs was the first to be preserved and organized as an archive within the NL, in a project funded by Fundación Andes in 1995-1996. 
The NL plays an active role in the preservation and assessment of national bibliographic materials from all eras considered fundamental to the collective memory and cultural heritage of the country.

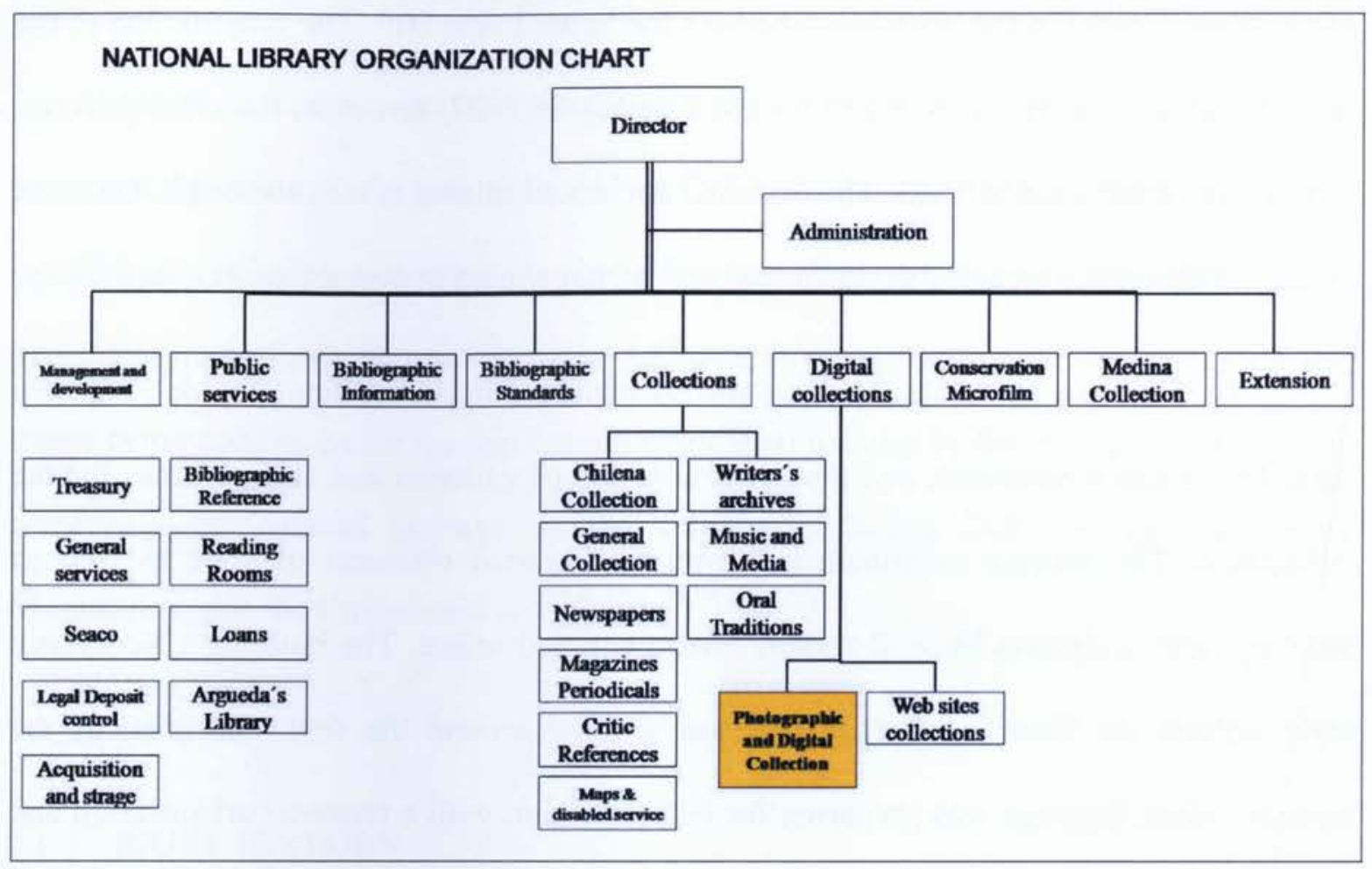

In addition to the General Collection, the Chilena Collection, and the Newspapers and Periodicals, the NL Special Collections Department is also impressive. It incorporates the Music and Media Archives, the Writers' Archives, and the Oral Traditions Archives. ${ }^{16}$ In 2007, due to active digitization programs, a Digital Collections Department was created to hold the Photographic and Digital Archives and the Web-based collections, which the NL recently began to collect.

16 [In Spanish, my translation] Música y Medios múltiples, Archivo del escritor, Archivo de Tradición Oral. 


\subsection{MISSION AND VISION}

The mission of the National Library of Chile is to collect, preserve, and provide access to diverse bibliographic materials, including print and other kinds of media, that constitute the collective memory of the country, with the aim of facilitating access and knowledge of the collection's valuable contents to the public, from the national and international community. ${ }^{17}$ [In Spanish, my translation]

Like most other countries, Chile has a Legal Deposit Law, number $19.733^{18}$ approved in June 2007, which determines that every publisher must send a number of copies of every publication printed in Chile to the NL in order to ensure free access to the information and culture to all citizens. As the law directs, the NL receives fifteen copies of all national registered printed publications, and two for other kinds of media such as sound records, audiovisual, and electronic materials.

The NL also provides high quality information services to the public, as well as reproductions, training, and other kinds of professional consulting services for other cultural institutions. The improvement of these services is based on constant communication with the public ${ }^{19}$.

$17 \quad$ Available at:

http://www.dibam.cl/biblioteca nacional/contenido.asp?id contenido=196\&id subsubmenu=204\&id subme $\frac{\mathrm{nu}=205 \text { \&id_menu }=8}{18}$

Legal Deposit Law 19.733, articles 13 and 14. Available at: http://www.dibam.cl/biblioteca nacional/contenido.asp?id_contenido=215\&id_submenu=214\&id menu

The NL records all public services and prepare statistics every six months to control all departments. Moreover, the Public Services Department is performing surveys periodically in the reading rooms as well as online. 
The NL is an active member of the International Federation of Library Associations (IFLA) as well as the Association of National Libraries of Iberoamerica (ABINIA), ${ }^{20}$ with goals to encourage and develop international cooperative relationships with bibliographic and cultural centers throughout the world.

\subsection{POLICIES AT THE NATIONAL LIBRARY}

A general introductory text about Institutional Policy is published on the website of the institution, which gives a broad outline of the objectives and main definitions of NL collections. According to the Head of Collections, there is a Collections Development Policy that was written by a special working group in 1998, but this document has never been officially approved nor published. Other issues with this unofficial policy are its lack of recent reviews and the general unfamiliarity of the library staff with its contents.

However, there is agreement within the professional staff, ${ }^{21}$ including the recently elected Director, that this document is considered too simplistic and insufficient for such a large and important institution.

During periods of field research, a number of incidents have occurred evidencing the lack of standard procedures and criteria to confront problems such as unwanted

20 [In Spanish, my translation] Asociación de Bibliotecas Nacionales de Iberoamérica. Available at: http://www.bibliotecanacional.gov.co/ENTIDAD/bibliotecas.htm\#abinia

This belief is available in the survey answered by the NL Head of Collections, Mrs. Marjorie Peña, included in the Appendix section of this thesis. 
donations, de-accession and disposal of duplicated materials, and collecting important original digital works, which today are becoming increasingly problematic ${ }^{22}$.

As mentioned earlier, the NL collecting activity rests predominantly on the Legal Deposit Law, which is also very broad and vague and has no specific regulations, leaving many aspects open to the personal interpretation of publishers, administrators, and librarians. In this matter, the NL has a special department in charge of controlling publishers and related companies to fulfill the law.

On the other hand, there is an acquisitions committee that meets regularly to evaluate all acquisitions proposed by the different departments of the NL, to ensure that purchases are made in agreement with the NL's general principles and scope within the actual budget restrictions.

Some departments have been encouraged to write specific internal policies. Such is the case of the Photographic and Digital Archives, but the model is still the same: extremely broad definitions and a lack of established rules and procedures.

22 One example of this happened in March, when examining the storage room, a group of over a hundred $35 \mathrm{~mm}$ rolls of film where found, and took over three months to have them re-destined to the Film Archives of Palacio La Moneda, because there were no records of the acquisition, they had no accession numbers and there were no written procedures to support the decisions of move them to other institution. 


\section{LIBRARY}

The Photographic and Digital Archives (PDA) is the section that holds the most extensive and important collection of photographic materials at the NL. It comprises approximately 40,000 photographs of diverse processes and formats and over 1,000,000 digital images, as a result of iconographic reproduction of the NL collections on paper support $^{23}$ and the high resolution masters of Memoria Chilena and Cervantes Virtual Library.

Nevertheless, other sections of the NL also have photographic materials such as the Medina Collection, the Writers' Archives, the Music and Media Archives, and the Oral Traditions Archives, each housed within its own separate storage room although the PDA has the responsibility to train the people in charge and to assist them in the preservation and access of the photographic materials according to NL standards.

The PDA collections include many different types of photographic processes such as daguerreotypes, photographic prints of all kinds (albumen, collodion and gelatin silver prints, etc), glass plate and plastic-based negatives, photographic albums, slides, and digital files, produced anywhere from the 1850's through to the present. The most important subjects covered are $20^{\text {th }}$ century literature, history, art and architecture, featuring many portraits of prominent figures of the country as well as common unnamed people.

23 $\underline{\mathrm{enu}=9}$ 
The collection value is significant because of its historical character, containing a great amount of unique information for use by both the general public and specialized researchers.

Due to the rapid development of the digital imaging culture, the PDA is actively participating in digital preservation initiatives, leading the collecting activity of such materials and researching digital collection issues within the institution with the purpose of preparing the NL for the technological and cultural realities of the $21^{\text {st }}$ century.

\subsection{HISTORY AND CURRENT ACTIVITIES}

The PDA was created in 1997 with the goal of becoming the specialized department dedicated to the preservation, research, and dissemination of the Chilean photographic heritage of the NL. PDA collections and resources are used to inspire and educate the national community about the historic and aesthetic values of photography as an expression of their cultural identity.

Although 1997 was the official inception date of the PDA, photographs have been part of the NL since its origin, though they were dispersed in several different departments. In 1995, during the implementation of a large project for the Medina Collection, an important group of $19^{\text {th }}$ century photographs and albums were found, mixed in and bound with maps, manuscripts, engravings, and drawings. All photographic materials were separated, organized by format and type of process, stored in conservation housings, digitized, and catalogued. 
A team specially trained in photographic conservation began work at this stage of the project, creating an appropriate storage room for the collection and introducing standards for the preservation of this type of material within the institution.

In 1996, one of these conservators ${ }^{24}$ was hired to expand this archive and organize the photographs throughout the NL into one centralized archive. ${ }^{25}$ During the early years, the PDA depended on the Special Collections Department, until 1997 when the Digital Collections Department was created. As a result of the digitization programs carried out by the NL, this new department comprises both Memoria Chilena $^{26}$ and the PDA.

The PDA collections are organized into three main sections: photographs, iconography, and digital material (see chart below). The Photographic Collections are subdivided into smaller groups, one of which is the General Collection, which is miscellaneous because it contains various types of

\section{COLLECTIONS ORGANIZATION CHART}

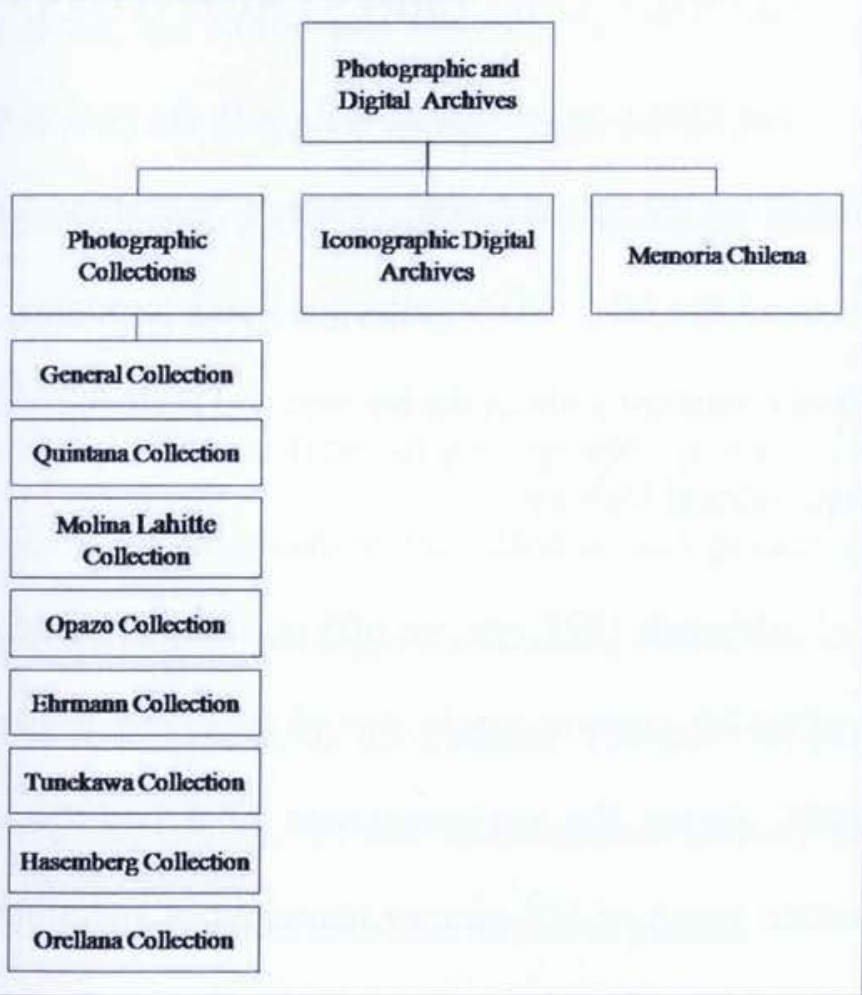

24 Roberto Aguirre, conservator of photographs was the Head of the PDA from 1996 to 2007. Today PDA also has two people working on preservation and cataloguing and one person doing digitization and reproduction.

${ }_{25}$ Excluding the Medina Collection, Writers', Music and Media, and Oral Tradition Archives; they kept their own collections with the purpose of not altering the context of the photographs.

26 Memoria Chilena is the National Library's Content Website, which today produces around 250,000 digitized pages every year. 
photographs, authors, and subject matter, and the other groups, which are organized by photographer because they each contain an important collection of the work of an individual photographer. The PDA has acquired seven photographers' collections to date, most of them pertaining to the period since 1930 to 1980 . Some essential $20^{\text {th }}$ century photographers in the collection are Antonio Quintana and Jorge Opazo y Alfredo Molina La Hitte.

The physical arrangement is determined by photographic processes and dimensions, using a system developed by the National Centre of Photographic Heritage, ${ }^{27}$ which uses four sizes of metal cabinets with drawer sizes depending on the size of

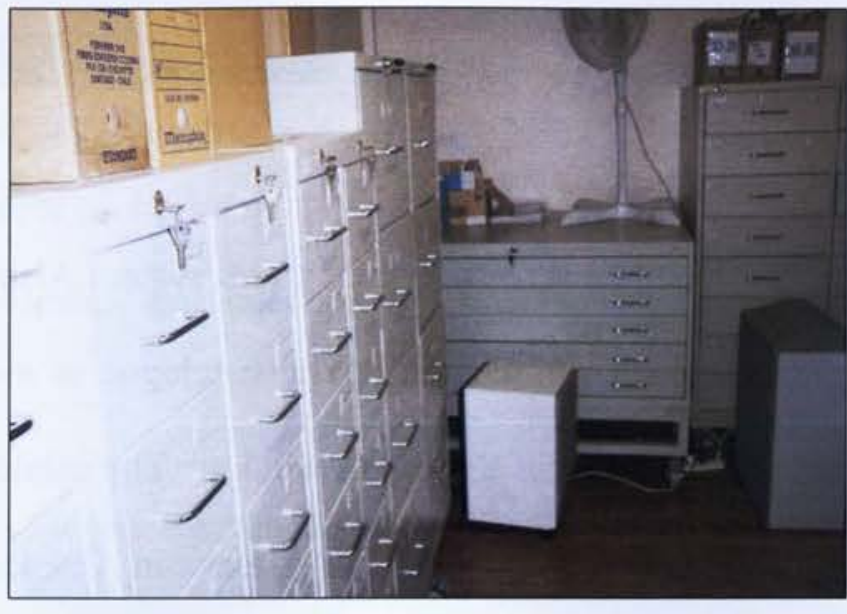

PDA storage room (Courtesy of PDA) the object (see illustration). All photographic prints as well as negatives are housed in conservation paper envelopes. ${ }^{28}$

The collection is available online (see next illustration) as well as in the print room. There are restrictions for accessing the originals because of conservation issues, with this access awarded only members of the public who specifically request this service. They are provided with cotton gloves and are supervised in the handling process by someone from PDA.

\footnotetext{
27 [In Spanish, my translation] Centro Nacional del Patrimonio Fotográfico. Available at: www.patrimoniofotografico.cl

${ }_{28} \quad$ Both paper and adhesive are approved through the Photographic Activity Test by the Image Permanence Institute.
} 
The cataloguing and

documentation process has

evolved through the years,

from a paper form in the

first years into a Microsoft

Office Excel spreadsheet,

followed by a database on

Microsoft Office Access,

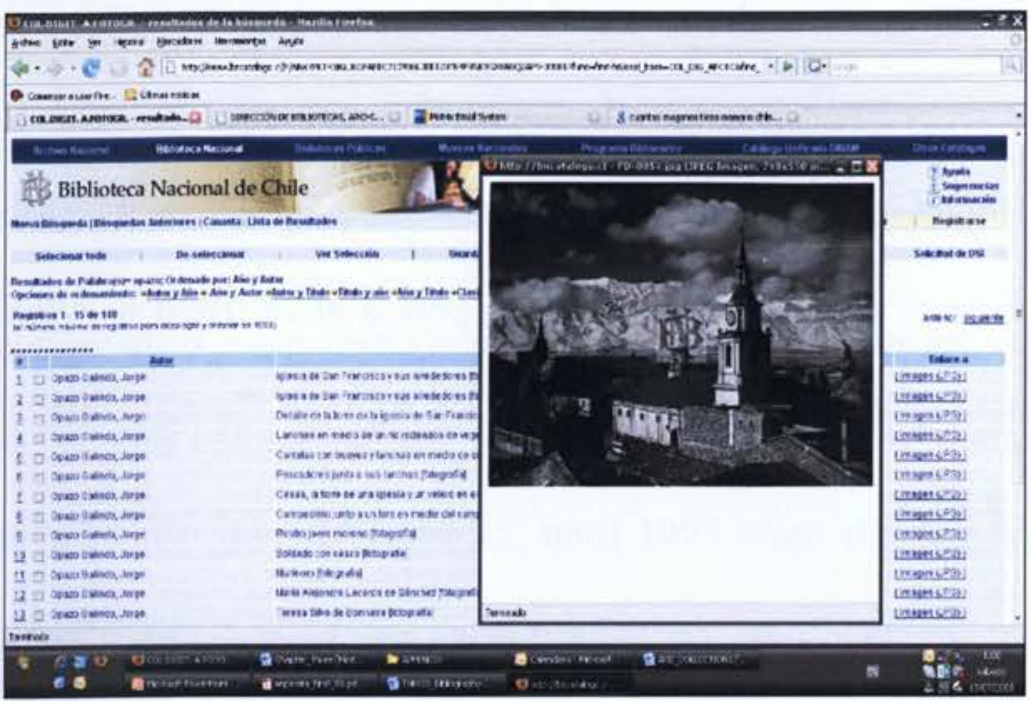

Sereen of the PDA online catalogue. Available at: www.bncatalogo.cl

which included a miniature

of the image on screen, to the current system Aleph, ${ }^{29}$ which is also used by the NL and all public libraries of DIBAM. The catalogue is available online,$^{30}$ where it is possible to access the image in a separate window. The cataloguing is carried out under NL standards, which incorporates the Anglo-American Cataloguing Rules, Marc Format for subject headings, controlled vocabulary based on the thesaurus, and the Collective Bibliographic Authority Catalogue. ${ }^{31}$ This system was adapted to photographic materials by a working group in 2006.

Other activities carried out by the PDA are the digital reproduction services for the entire NL, as well as preparing exhibitions, publications, and content for Memoria Chilena,

29 Aleph Integrated Library System. Available at: http://www.exlibrisgroup.com/category/Aleph 30 The public online catalogue of Dibam's libraries use Aleph Integrated Library System, whose operating system is Linux Red Hat; the information is stored in an Oracle database. Web-pages are HTML. Available at:

http://www.dibam.cl/biblioteca nacional/contenido.asp?id_contenido=109\&id_submenu=164\&id menu=10 31 Bibliographic description based on the Anglo-American Cataloguing Rules, 2nd edition. The access points use the principles established by the Library of Congress Subject Headings List in its local version called Collective Catalogue of Bibliographic Authorities [In Spanish, my translation]. 
and providing consulting and training to other public institutions as well as private collectors.

\subsection{CURRENT WRITTEN POLICY, A CRITICAL REVIEW}

As mention earlier, the current PDA collection development policy was created as part of the process of the general development policy of the NL in 2006, which has been translated by the author and is included in Appendix 3 of this document.

The current policy document is three pages long, and it has been divided into three main sections: introduction, mission statement, and selection criteria, which includes the general scope and forms of acquisition.

The document is very broad and establishes the department's mission statement, objectives, and main collecting interests and scope in succinct sentences. It includes all photographs produced in Chile or by Chilean photographers elsewhere in a time span from the $19^{\text {th }}$ century to date, and provides modest concrete directives regarding collecting desirable subject matters or photographic genres.

One aspect that has not been mentioned in this document is that there is a nonofficial agreement between the NL and the National Historical Museum photographic archives about concentrating the $19^{\text {th }}$ century's photographs collecting activities in the museum while the $20^{\text {th }}$ and $21^{\text {st }}$ centuries' photographs are held in the NL. This situation came up after a conflict when the NL started officially collecting photographs, and the museum's authorities at the time did not agree with the existence of two photographic 
archives within Dibam. ${ }^{32}$ A written policy should help to create understanding and agreement between the two institutions.

Also, general policies and the Deposit Law make no mention of photographs, so there is no legal framework that compels authors to give their work to the NL; for this reason, the policy should help to encourage donations directly from photographers.

In summary, the key problems identified with the current policy are:

- This policy needs to cover in detail other subjects such as acquisitions, loans and disposals, documentation, conservation and preservation, storage security and movement, and access to collections ${ }^{33}$.

- Rules and written procedures need to be set up to complement and enforce the policy to help make it more effective.

32 This polemic situation still creates some problems; nevertheless, many local and specialized museums, libraries and archives have established their own photo archives over time, achieving great results within their communities, as mentioned in Chapter 1.

33 See appendix2: Policy Draft, where all this topics are developed with detailed recommendations. 
In order to create a methodology for a collections policy, from the drafting process, to the application, to dissemination within and outside the institution, many strategies were used. Foremost was the compilation of bibliographic sources as well as consultations with professionals committed to collections management in different types of institutions. Another key aspect of this research was carried out by consulting websites of similar institutions, which offer online a substantial amount of worthwhile information about their policies.

In addition, a written survey was sent to thirteen photographic collections managers at various Chilean institutions, as well as to national libraries in Latin America and elsewhere. $^{34}$ Eight responses were received, providing valuable input to complete this work. The complete analysis of the results of this survey can be found in Appendix $4^{35}$.

The methodology and structure of this proposal was based on three main sources: the Collection Development Training Website (CDT) ${ }^{36}$ which is supported by the Arizona State Library, Archives and Public Records (U.S.); the Collections Policy of the National Library of New Zealand ${ }^{37}$; and the Collections Management Policy of the National

34 In Chile: National Archives, National Historical Museum, National Library. Latin America: National Library of Perú, National Library of Argentina, National Library of Colombia, National Library of Venezuela, Montevideo City Hall Photographic Centre. Elsewhere: National Library of Australia, National Library of New Zealand, National Library of Spain, Library and Archives Canada, and U.S. Library of Congress.

$35 \quad$ Appendix 4: Survey results.

36 Available at: http://www.lib.az.us/cdt/

37 Available at: http://www.natlib.govt.nz/about-us/policies-strategy/our-policy-about-collections 
Museum of Science and Industry (U.K.), ${ }^{38}$ which is a family of British museums that are part of the National Media Museum.

Preparing a Collections Policy is a complex process. Because its benefits are not seen by the general public, it often does not receive high priority. For this reason, there is not much interest in dedicating quality time to its development. In addition, it requires the commitment of a team of people to discuss and draft the policy and to anticipate how it will affect the institution's departments and processes, a time-consuming task indeed. However, a structured working methodology can make the task easier and more manageable.

In most cases, institutions have their own general policy already established; this provides a structure and format for the individual sections to follow. Unfortunately, this is not the case with the NL, where the department in question is preparing its own policy based on an unofficial existing document.

The following steps provide an outline of the main activities proposed ${ }^{39}$ :

a. Establish the procedure and the team:

This includes consultation with the Governing Board, led by the Director, obtaining their approval to carry out the process, as well as the choosing of working members of the team and creating a workflow with deadlines attached.

b. Gather bibliography and collection data:

The policy needs to take into account information gathered from internal institutional documents. Some of this data can be adapted from the Strategic Plan. Existing

\footnotetext{
38 Unpublished draft sent by the person in charge during other research carried out in 2006.

39 Based on the online tutorial Preparing a Collection Development Policy. In: Collection

Development Training Website (CDT). Available at: http://www.lib.az.us/cdt/
} 
policy statements and written procedures can be useful, as well. Another important task to carry out is a collections assessment, to determine the strengths and weaknesses of the existing materials.

c. Write the policy:

Establish the policy sections and the general structure of each (e.g., context and definitions, acquisition policy). Develop a manual of style to guide the writing and assign the writers, editor, and readers within the team. It is prudent at this point to contact a member of the institution's legal department to ensure that the policy team is knowledgeable in areas where legal issues are involved.

\section{d. Obtain the approval of the Board of Governors:}

After the policy is fully drafted and thoroughly reviewed, the institution's Director should present the policy to the Board of Governors for approval. Once approved, the policy is ready to be officially implemented by the institution.

e. Use and dissemination:

After the policy has been adopted, written procedures should be defined based on the policy. The policy should be reproduced both as a printed booklet and electronically on the website of the institution, with the aim of informing all staff as well as members of the community.

f. Revise and update the policy:

Set a schedule for revising and updating the policy. It is recommended that the policy should be reviewed at least every three years. 


\subsection{OBJECTIVE}

The objective of this report is to create a methodology for developing a collections policy for the PDA, primarily based on existing bibliography and similar institutions' previous experiences, with the idea of providing a model for other departments and collections of the NL to follow in the near future.

\subsection{DESCRIPTION OF THE MAIN TOPICS INCLUDED}

The proposed policy document is divided into five main sections, including all processes and activities related with the photographic objects within the $\mathrm{PDA}^{40}$ :

\section{Description of the Collection}

This section provides general information about the department such as the mission statement, objectives, size and scope of the collections as well as the strategic vision.

\section{Collection Development Policy}

III. Practical Elements of Collection Management Policy

- Acquisitions, loans, and disposals - building and managing the collection to ensure it complies with the mission statement of the NL. Providing a list of key artefacts/names to be included in the collection as well as describing the methods of acquiring them.

- Inventory, cataloguing, and documentation - ensuring the appropriate organization and registration of the collection and its accurate documentation through catalogues, 
while providing access to the public in accordance with NL cataloguing and description standards.

- Preservation and preventive conservation - including all indirect actions to ensure proper care, such as those involving storage, security, risk management, exhibiting, and transport.

- Conservation and restoration - ensuring the physical and chemical stability of the collection's objects by applying direct treatments, while retaining its aesthetic values based on standard principles.

- Access - providing physical, intellectual, and emotional access to collections, both inside and beyond the PDA.

IV. Official Adoption and Revision Information

This section describes the adoption and review plan, proposing a committee for these processes. 


\section{CONCLUSIONS}

The choice of collections policies development as a thesis subject was made at the optimum place and time possible. The NL has a new Director who is trying to address a number of issues that are not resolved at the institution, especially those related with digitization and innovation of public access to collections. To address this key undertaking, a "Digital Working Group" was recently formed. This strategy has provided the opportunity to introduce the collections policy discussion at the institutional level. Coincidentally, there has been a major staff turnover during the last year (because of a massive retirement of people), which helps to facilitate change in such a traditional institution.

On a larger scale, DIBAM has also created a "Digital Policy Committee," which is studying the problem at a national level (including all libraries, archives, and museums in Chile), that has revealed a lack of standards and procedures in other basic areas (e.g., copyright, uses, and reproductions). This fact will resolve many issues before the digital policy comes into effect. Most concerns centre around what to collect, how to collect, how to store, and how to preserve digital resources at DIBAM institutions, as well as how to use these new assets for the cultural development and education of the country.

Working with photographic collections in libraries is a challenge, especially since the standards in use are intended for books. This presents some problems, though in many aspects, such as acquisition, conservation, exhibition, and access, the reality is not too different from museums and archives. Consequently, policies tend to be similar. 
The results of this research process are based on the Policy Draft Proposal for PDA, included in Appendix 1. Writing this document has not been an easy task, especially since there are many sections that need to be highly detailed and the use of language is a key element in order to produce a comprehensive, clear document. Fortunately, there are good examples and manuals available online from other institutions, though it must be remembered that policies documents should respond to specific institutional realities and background.

Writing policies requires studying collections in depth; this is an imperative step that helps to reveal the collection's strengths and weaknesses, and will show how well the collection represents the mission statement of the institution. These steps are crucial to setting up collecting strategies and a guide for new acquisitions, as well as generating research activities within the existing collection.

The exercise of creating a methodology has been a valuable experience because setting up a guide to writing a policy is helpful for many other institutions, even though this is not a unique idea. Our plan for the future is to provide an accessible design to this guideline's template and to upload it on the NL website, where there are other useful resources for library professionals and the general public.

The library world is all about information, and today information is available at the user's fingertips. Giving access to technical information, such as policies to the public, is the responsibility of large institutions because it improves communication with its users, helping them to understand the process of preserving cultural heritage, while at the same time providing access to the collections and contents. 
Finally, this research project has had a major impact on my career development during my short time thus far at the NL of Chile. It has given me the opportunity to speak with a number of key people involved with institutional development within Chile as well as to contact many curators and collections managers in other countries, especially within Latin America. Policy writing and application are complex tasks for any institution, and I am optimistic that showing effective results is a positive step that will encourage other photographic archives in Chile and other Latin American countries to begin this challenging and rewarding undertaking ${ }^{41}$. November 2008; this activity will help other institutions to start planning their policy writing based on the experience and methodology developed on this thesis work. 


\section{APPENDIX 1: PHOTOGRAPHIC AND DIGITAL ARCHIVES (PDA)}

Created in 1997, PDA is a specialized department dedicated to the preservation, research, and dissemination of the Chilean photographic heritage of the NL. PDA collections and resources are used to inspire and educate the national community about the historic and aesthetic values of photography as an expression of their cultural identity.

PDA collections encompass approximately 40,000 photographs of diverse processes and formats and over $1,000,000$ digital images, as a result of iconographic reproduction of the NL collections on paper support and the high resolution masters of Memoria Chilena and Cervantes Virtual Library.

PDA collections include many different types of photographic processes such as daguerreotypes, photographic prints of all kinds (albumen, collodion and gelatine silver prints, etc), glass plate and plastic-based negatives, photographic albums, slides, and digital files, produced from the 1850 's through to the present. The most important subjects covered are 20th century literature, history, art and architecture. The collection has a significant value because of its historical character,

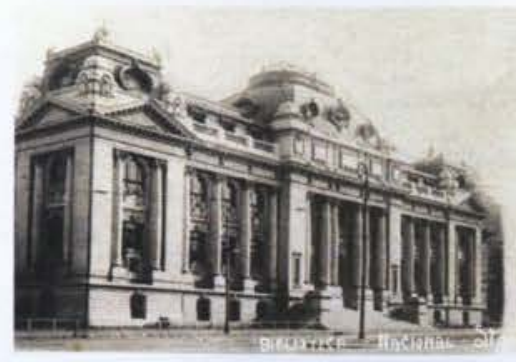

National Library 1925

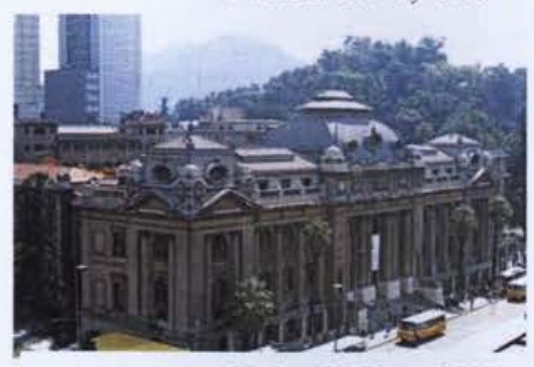

National Library 2008

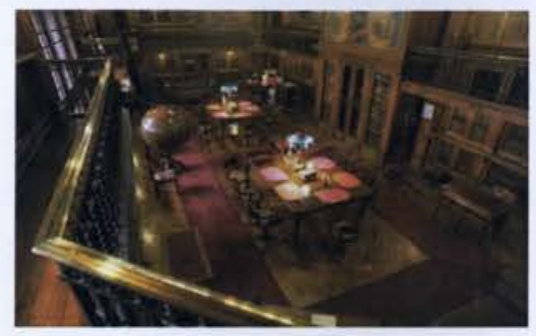

Medina Room

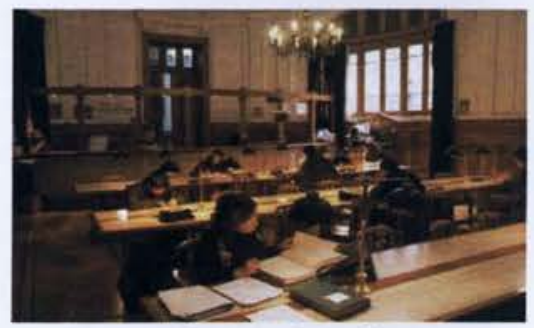

Gabriela Mistral Reading Room

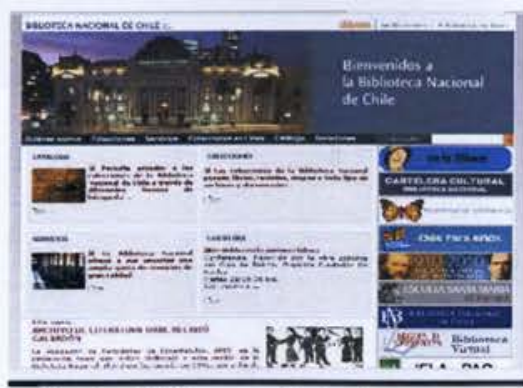

National Library website, home page 
containing a great amount of unique information for use by both the general public and specialized researchers.

Due to the rapid development of the digital imaging culture, the PDA is actively participating in digital preservation initiatives, leading the collecting activity of such materials and researching digital collection issues within the institution with the purpose of preparing the NL for the technological and cultural realities of the 21 st century.

PDA collections are organized into three main sections: photographs, iconography, and digital material, these sections are also are subdivided into smaller groups.

One of the most interesting aspects of PDA collection development is the acquisition of individual photographers' collections. Hitherto, PDA has seven authors, most of them pertaining to the period since 1930 to 1980 .

\section{Photographic Collection}

It has been organized into the following sections:

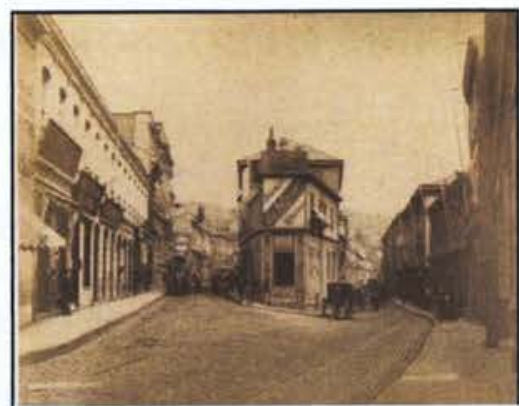

Valparaiso, Le Blanc Studio, ca. 1865

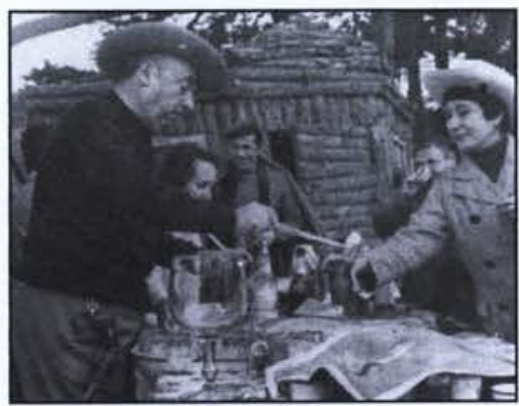

Pablo Neruda, Hans Ehrmann

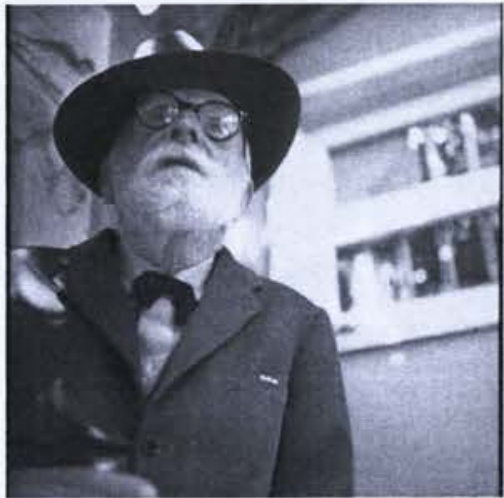

Pablo Burchard, Hans Ehrmann

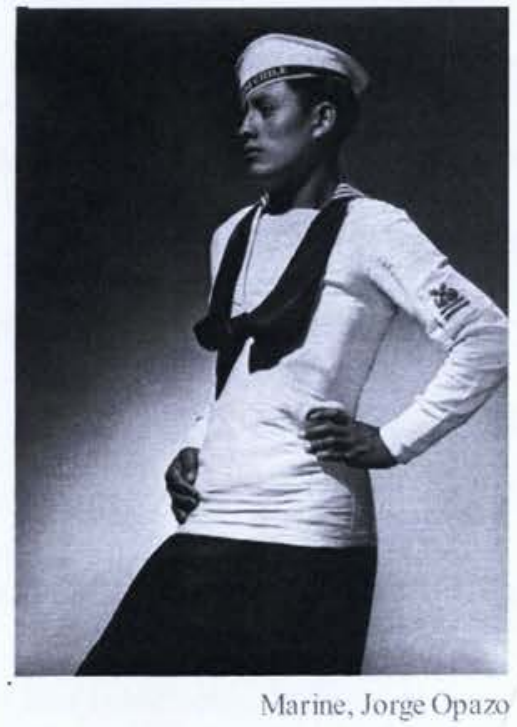


a. General Collection

This photographic collection is comprised of a variety of sizes and formats, photographic processes, subject matter and photographers. It includes all kinds of paper prints, negatives and slides, and photographic albums mostly from the $20^{\text {th }}$ century. Its main topics are portraits of all kinds, rural and urban landscape, social life, and family snapshots. Most photographs are focused in Chile as a common thread, such as photographs of and about Chile, as well as photographs by Chilean photographers elsewhere.

\section{b. Medina Collection}

This is one of the most valuable collections in the NL. Donated by the eminent bibliophile José Toribio Medina, it has around 5,000 photographs and rare albums, with valuable images of the society and culture of the $19^{\text {th }}$ century in Chile. It contains the few examples of cased photographs existing in the NL.

\section{c. Photographer Collection: Antonio Quintana}

With 4,000 photographic materials, this collection comprises the unique work of Antonio Quintana, who was a teacher and photographer of the Journalism School of University of Chile [My translation]. This collection

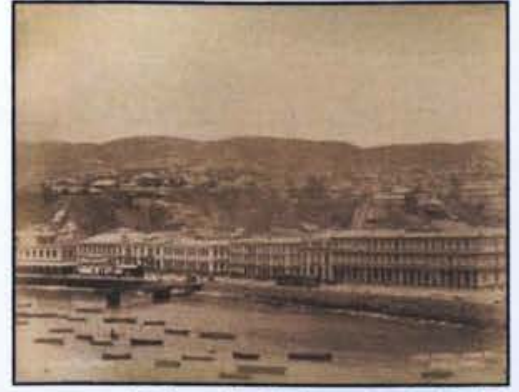

Valparaiso harbour front, N.d.

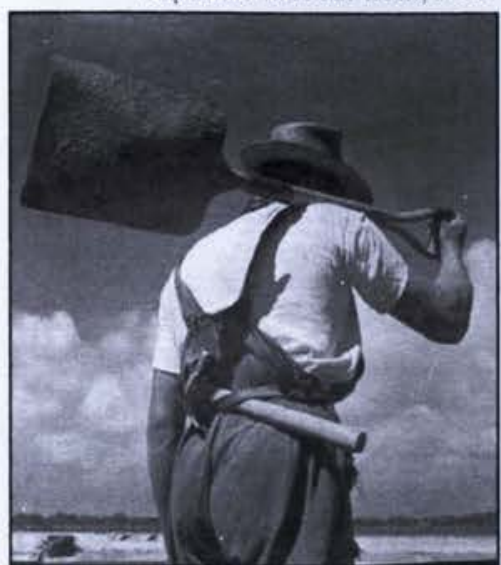

Worker, Antonio Quintana, Ca. 1960
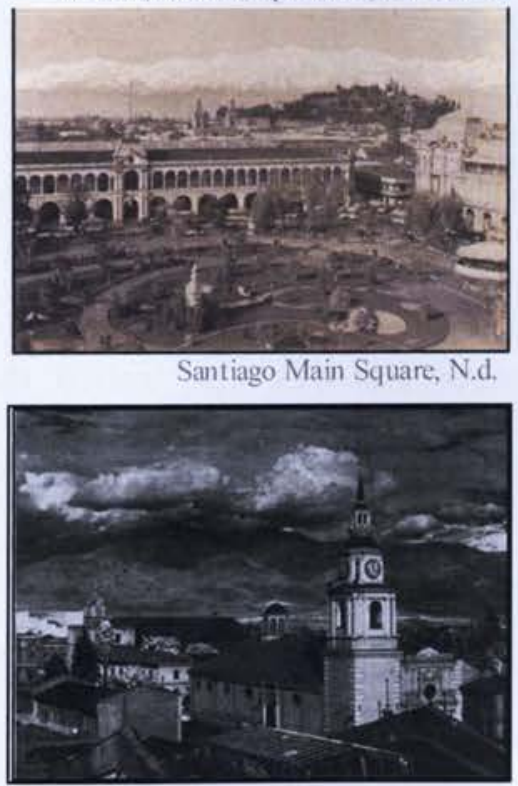

Santiago, Jorge Opazo, Ca, 1950

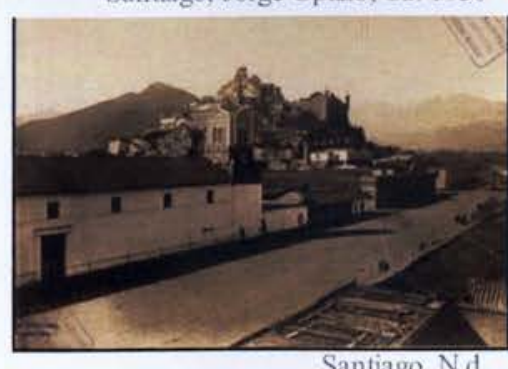


represents a complete record of cultural manifestations such as religious traditional celebrations, industrial and artisanal activities and other social documentary work from 1930 to 1972 . His most important work was the renowned book and exhibition called "The Chilean Face."

\section{d. Photographer Collection: Alfredo Molina Lahitte}

This collection is formed by 487 glass plates and acetatebased negatives. All photographs are studio portraits of the theatre and burlesque people, from the decades from 1930 's to 1960 , depicting a unique and unknown world

e. Photographer Collection: Jorge Opazo This small but important collection has 148 photographs by the wellknown photographer of the high society of Chile, Jorge Opazo. He was also called the photographer of the presidents because he was the official portraitist from 1930 to 1970. His photographs were published in the most popular illustrated magazines and newspapers of his time.

\section{f. Author's Collections: Hans Ehrmann}

This collection contains around 6,000 portraits, prints, and negatives of many formats, of people related with literature, art, dance, music, theatre, and movies of Chile
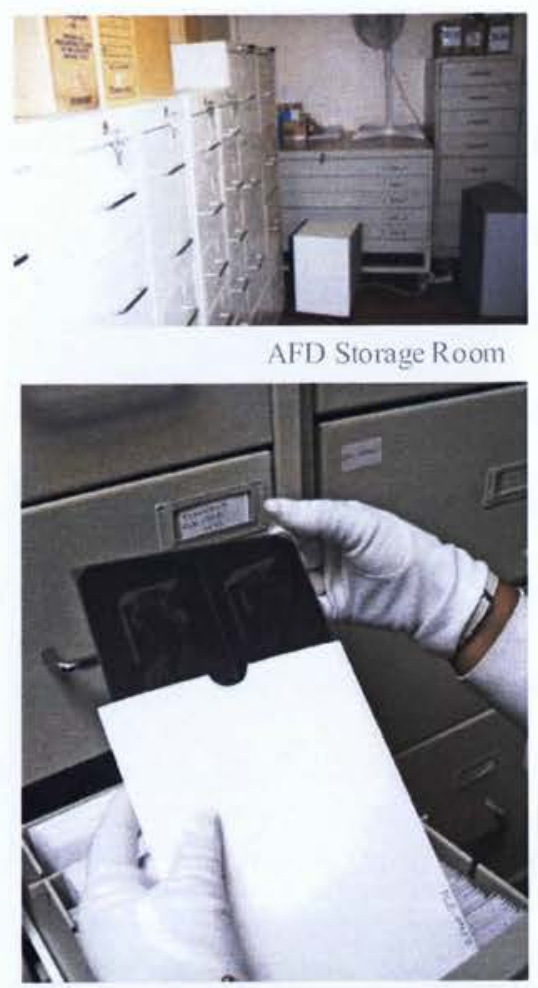

AFD Housing system

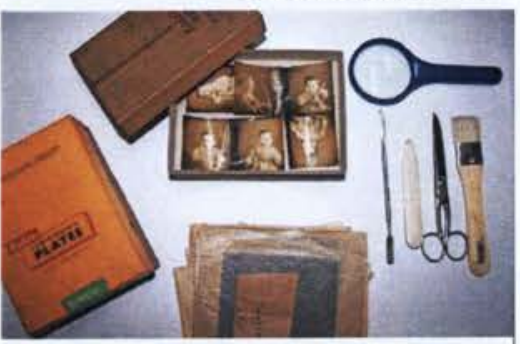

AFD working area

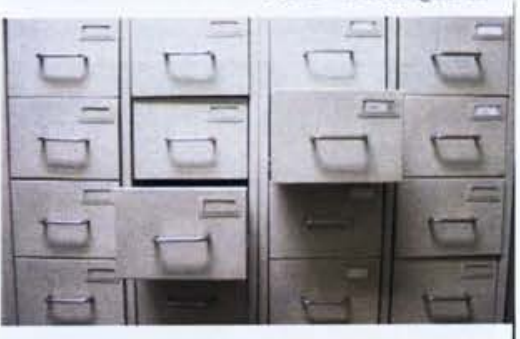

AFD Furniture

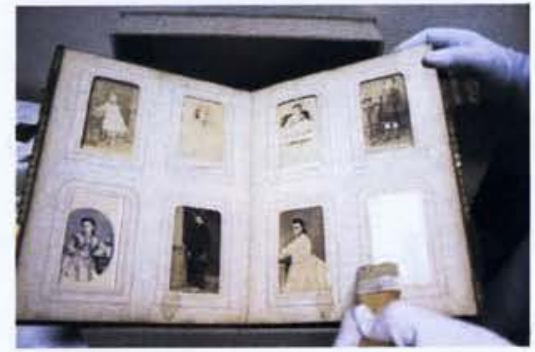

$19 t$ Century Album, General Collection 
and the rest of the world. Hans Erhmann was a prominent journalist who used photography as the medium of recording his encounters with many fascinating individuals.

g. Photographer Collection: Luis Ladrón de Guevara This collection of 1,125 plastic-based negatives represents the industrial development of Chile from 1940 to 1980.

h. Author's Collections: Kiutaro Tunekawa

It contains 1,233 prints and negatives from 1924 to 1985 . The collection has mostly individual and group classic studio portraits; many of them are hand coloured, which was the specialty of the Tunekawa Studio. It represents an important record of the Chilean upper and middle class of a large section of the $20^{\text {th }}$ century.

i. Photographer Collection: Gerd Hasenberg (In progress) It has 9,259 portraits of actors, directosr and other people from show business from 1960 to 1980 .

j. Photographer Collection: Aquiles Orellana(In progress) It has 12,300 negatives about the history of the Chilean theatre from 1958 to 1977 , as well as city views of Chilean and European cities.

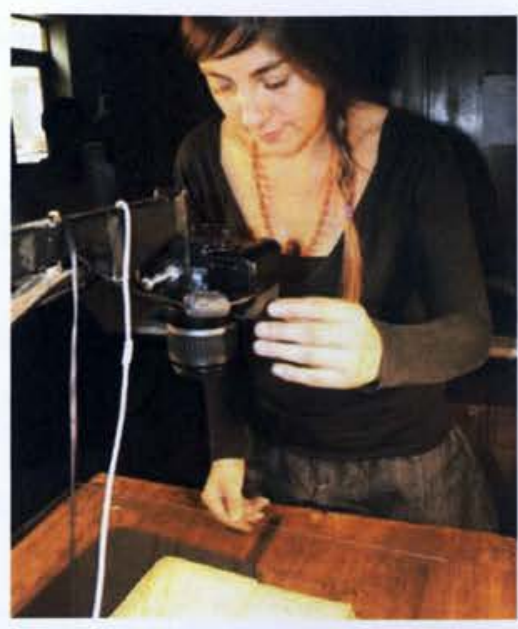

AFD activities: Digitization

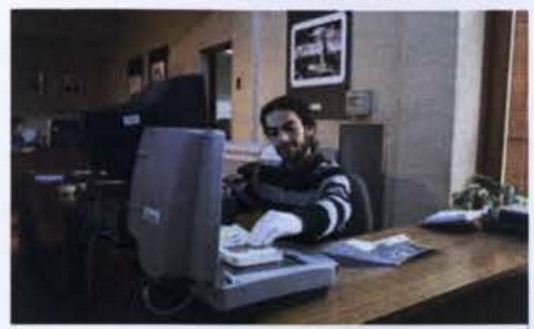

AFD activities: Digitization

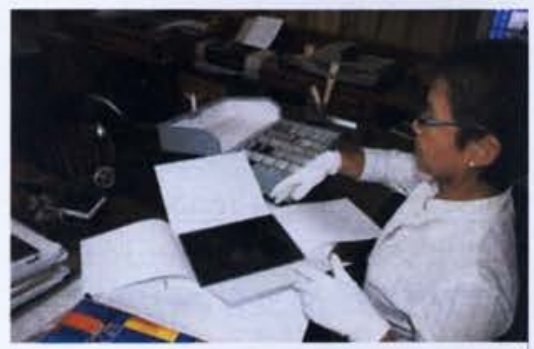

AFD activities: Handling

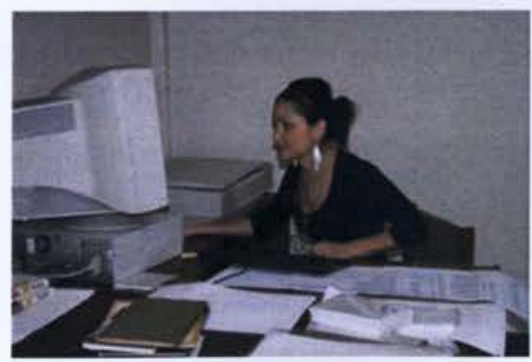

AFD activit ies: Cataloguing

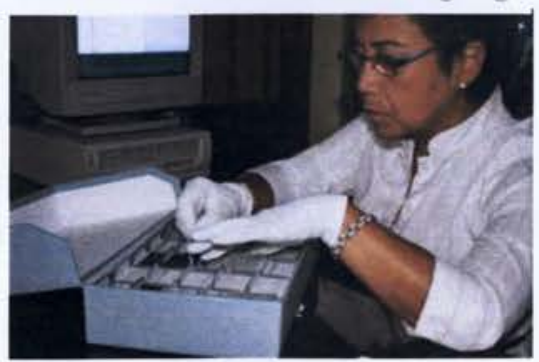

AFD activit ies: Cataloguing 


\section{Iconographic Digital Collection}

This collection has over 2,000 images which have been digitized from other paper-based collections of NL, such as newspapers, magazines, drawings, engravings, maps and manuscripts. The images have been organized by defined topics, related with Chilean history, politics and culture, among others, from the Colonial time to date.

\section{Memoria Chilena Collection}

It has over 1,000,000 digital images of bibliographic and iconographic materials of Dibam, which have been digitized through a programs intended to provide online contents in the website and digital library www.memoriachilena.cl, www.chileparaninos.cl, and http://www.cervantesvirtual.com/portal/BNC/.

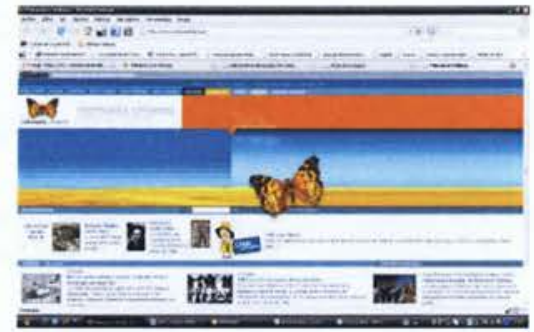

Memoria Chilena Home Page

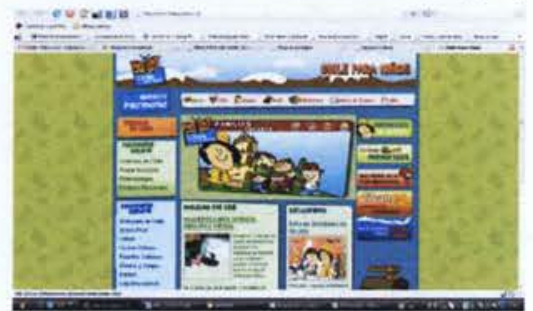

Chile Para Niños Home Page

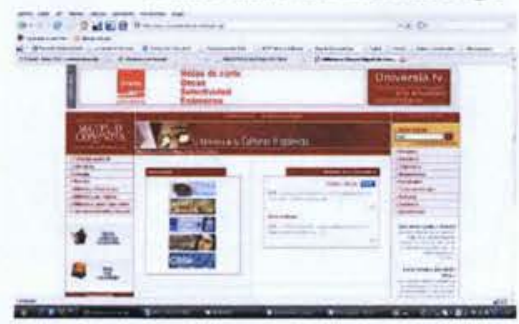

Biblioteca Virtual Cervantes Home Page 


\section{APPENDIX 2: DRAFT PROPOSAL PDA COLECTION POLICY}

\section{Description of the Collection}

The Photographic and Digital Archives (PDA) was created in 1997 with the aim of becoming the specialized department dedicated to the preservation, research, and dissemination of Chilean photographic heritage within the NL. PDA collections and resources are used to inspire and educate the national community about historic and aesthetic values of photography as an expression of their cultural identity.

Due to the rapid development of the digital imaging culture, the PDA is actively participating in digital preservation initiatives, leading the collecting activity of such materials and researching digital collections issues in the institution, with the goal of preparing the NL for the $21^{\text {st }}$ century technological and cultural reality.

The PDA's priority is increasing the size and quality of its collections, implementing donation programs, acquiring valuable materials, and generating its own digital objects, according to established development criteria, to offer more information to the general public and specialized researchers.

Today PDA collections hold approximately 40,000 photographs of diverse processes and formats and over 1,000,000 digital images, as a result of iconographic reproduction of the NL collections on paper support and the high resolution masters of Memoria Chilena.

\section{Mission Statement:}

The mission is to grant significance to the National Library's Photographic and Digital Collections, creating opportunities for the identification of the national community 
with this heritage through its historical and aesthetic value. PDA is committed to collecting, housing, researching, and disseminating the photographic heritage of the country. PDA will use its collections and resources to inspire and educate the national community in the art and different values of photography as an expression of their cultural identity.

\section{Collection Development Policy}

The PDA will acquire photographs representative of the history of photography in Chile and its technological and aesthetical evolution, with emphasis on the $20^{\text {th }}$ and $21^{\text {st }}$ centuries.

The PDA will acquire photographs that represent national photographers' creations from the first pioneers who arrived in the country in 1840 to the present, having special interest on those of the $20^{\text {th }}$ and $21^{\text {st }}$ centuries.

In keeping with these two goals, PDA is interested in the acquisition of: photographic prints (original, vintage, signed, edited), photographic negatives, photographic objects, and bibliography related with photography (photography books, illustrated magazines, catalogues, studio records) from the beginnings of photography in Chile to the present. This includes photographs with historical and documentary content related to the country, as well as photographs that represent artistic and cultural value.

At the present time, digital imaging is the main expression for photography. The PDA collection is interested in acquiring these kinds of materials to facilitate a greater understanding and appreciation of the contemporary visual world and to preserve it for future generations. 
The photographic acquisition strategy has identified six major thematic areas ${ }^{42}$ for future acquisition:

a. culture, defined as the traditional and contemporary values, beliefs, customs, and habits of the Chilean society;

b. cultural industries, including all kinds of artistic and intellectual activities and their main personalities;

c. economy, including business, labour, science and technology, and industries of the country;

d. political and public life, including all institutional activities such as religious, military, governmental and nongovernmental; and

e. social life, including organized groups and individuals within civil society and their relationships and activities.

Under the current organization of PDA collection, the acquisitions will increment the three main collections: Photographic Collection, Iconographic Digital Collection, and the Memoria Chilena Collection (digital).

The selection parameters used in the evaluation of new acquisitions are:

- Historic value (established by specialists)

- Aesthetic value (established by specialists)

- Research value (demanded by users)

42 Based on Library and Archives Canada Canadian Archives And Special Collections Branch Acquisition Orientation 2006 - 2001, provided by Jim Burant, Chief, Art and Photo Archives, Libraries and Archives Canada. 
There are three forms of acquisition of photographic and digital collections that have been previously evaluated by the General Acquisitions Committee of the National Library, as follows:

- Internal production (Memoria Chilena, reproduction services, activities records archive)

- Collection purchase (annual budget assigned by an acquisitions committee)

- Donation reception (through public campaigns and contact with photographers and photographic studios)

\section{Collection Management Policy}

\section{Acquisitions, loans, and disposals}

\subsection{Acquisitions}

Photographic and digital items will be acquired in accordance with the Collection Development Policy to ensure that it complies with the mission statement of the NL. Moreover, every new acquisition will be carried out according to PDA established acquisition procedures and will be properly documented.

In this context, acquisitions may be made by:

- Gift or donation (made during the life of donor)

- Bequest or legacy (made from a will)

- Purchase (direct from photographers, auctions, private collectors, exchange)

- Field Collection (in the case of photography could be the result of surveys, research, exhibits, and national concourses, such as Fondart) 
- Conversion (the unauthorized assumption of ownership of property belonging to another)

Gifts or donations will be accepted with no restrictions of exhibition and use. In these cases, the donors will transfer the object and all of the rights of exhibition, use, and reproduction, by signing a special PDA form.

Potential acquisition must be evaluated in relation to PDA objectives and its financial capabilities and physical facilities to ensure the ability of PDA care for photographic objects according to their particular needs.

Every acquisition requires documentation of the original object, such as previous ownership information and uses of the photographs.

New acquisitions must meet the legal standards of the Intellectual Property Law $\mathrm{N}^{\circ}$ 17.336 .

Potential acquisition will be evaluated by the PDA Specialized Acquisition Committee, whose members include a representative of NL governing body, a photographer with a relevant and recognized career, a representative of the critic and theory of art (photography curator), an historian with a background in history of photography, a conservation specialist, and a lawyer with an expertise in copyright issues and cultural policies.

This Committee will evaluate the quality of the acquisition, establish its relevance for the PDA Collections, and study provenance and conservation conditions of the potential acquisition. 


\subsection{Loans in and out}

PDA will accept items into the collection as loans only under exceptional circumstances and will not accept items on permanent loan. Both PDA and lender will complete and sign a written agreement for all inward loans.

Inward loans will always be for a fixed period, depending on its purpose. However, the current policy is that all loan agreements must ultimately be terminated either by the return of the item(s) to the lender or by their acquisition into the permanent collection.

Loans in will be subject to the same standards of care and accountability as items in the permanent collections, with regular condition checks.

No conservation treatments will be performed on loaned-in items without the written consent of the owner.

PDA will lend collection items to other institutions, for exhibition and research purposes, with the stipulation that they meet PDA standards for conservation, access, security, and display conditions. PDA and the borrower will complete and sign a written agreement for all outward loans.

Borrowers may not carry out conservation treatments on PDA items without the prior agreement and evaluation of a PDA conservation expert.

\subsection{Disposals}

The collections will be regularly reviewed to ensure compliance with the PDA Collections Development Policy. Items that do not fulfill the current Policy will be evaluated and disposed of. 
Disposal will be carried out according to DIBAM legal procedures by one of the following means:

- Transfer to internal non-collections use (for instance, handling or study collections)

- $\quad$ Return to the donor

- Transfer to another registered museum

- Destruction

PDA will keep complete records of all disposals and will provide a copy for the Legal Department of DIBAM.

\section{Inventory, cataloguing, and documentation}

PDA will maintain an updated record of all acquired items, including comprehensive documentation of the smaller collections acquired separately, along with the history, provenance, acquisition, and loans of every one of these collections.

The cataloguing and documentation is carried out using the NL catalogue Aleph, available online at www.bncatalogo.cl, which provides a window with a miniature of the image.

The cataloguing is carried out under NL standards, which incorporates the AngloAmerican Cataloguing Rules, Marc Format for subject headings, controlled vocabulary based on the thesaurus, and the Collective Bibliographic Authority Catalogue.

The cataloguing will be periodically reviewed by a Librarian and the Head of the PDA to ensure the quality of the records. 


\section{Preservation and preventive conservation}

PDA will actively seek to minimize the physical, chemical, and biological deterioration of the photographic and digital items in its care by ensuring that they are stored or displayed under conditions appropriate for each type of material.

These actions include the on-going recording of temperature and relative humidity in the storage rooms, routine cleaning, and the periodic maintenance of the climate control equipment.

\subsection{Conservation and restoration}

PDA will carry out conservation treatments on the collections to remove or stabilize the effects of physical, chemical, or biological deterioration so that the items may be used and enjoyed by the public.

All conservation treatments aim to preserve the object's physical, historical and cultural integrity. Materials and methods used will fulfill professional best practice. All treatments will be accurately documented and will be added to the documentation of the collection.

Restoration treatments will be restricted to special cases and will be carefully evaluated in coordination with the NL Conservation Lab. 


\section{Access}

PDA will provide and promote physical access as well as intellectual and emotional access to its collections, with the purpose of engaging people with its cultural contents and meanings.

Physical access is ensured by exhibitions in the NL, by loans of material for display at other venues, and through visits to the print room by appointment.

Intellectual access to the information of collections is provided by the electronic catalogue which is available online as well as in the reading rooms inside the NL.

\section{Official Adoption and Revision Information}

This policy will be presented formally by the NL Director to the Governing Board for approval. Once approved, the policy will be officially implemented.

The Head of PDA will evaluate the policy once a year and present a formal report. The NL Collections Management Committee will review the policy at a maximum of five years from the date of its ratification by the Governing Board of the NL.

After the policy is adopted, written procedures will be written based on the policy. The policy will be available in a paper booklet as well as in an electronic version on PDF format on the website of the institution, with the aim of informing all staff as well as members of the community. 


\section{APPENDIX 3: CURRENT COLLECTION DEVELOPMENT POLICY}

\section{Collection Development Policy: Photographic and Digital Archives 43}

Identification of the Department:

Photographic and Digital Archives

\section{Introduction:}

The Photographic and Digital Archives (PDA) was created in 1997 with the aim of becoming the specialized department dedicated to the preservation, research, and dissemination of Chilean photographic heritage within the NL. PDA collections and resources are used to inspire and educate the national community about historic and aesthetic values of photography as an expression of their cultural identity.

Due to the rapid development of the digital imaging culture, the PDA is actively participating in digital preservation initiatives, leading the collecting activity of such materials and researching digital collections issues in the institution, with the purpose of preparing the NL for the $21^{\text {st }}$ century technological and cultural reality.

The PDA's priority is increasing the size and quality of its collections, implementing donation programs, acquiring valuable materials, and generating its own digital objects, according to established development criteria, to offer more information to the general public and specialized researchers.

Today PDA collections hold approximately 40,000 photographs of diverse 
processes and formats and over 1,000,000 digital images, as a result of iconographic reproduction of the NL collections on paper support and the high resolution masters of Memoria Chilena.

\section{Mission Statement:}

The PDA's mission is to grant significance to the National Library's Photographic and Digital Collections, creating opportunities for the identification of the national community with this heritage through its historical and aesthetic value.

\section{Selection Criteria:}

\subsection{Subject matter scope:}

\section{Photography collections:}

a) Collecting and safeguarding important photographic material to generate new research sources to create knowledge on diverse matters, particularly literature, art, and the social sciences.

b) Collecting relevant materials for the construction of the history of photography in Chile.

\section{Digital collections:}

a) Collecting iconographic materials from digitization projects such as Memoria Chilena.

b) Collecting iconographic materials from the reproduction services of the 


\begin{tabular}{|c|}
\hline NL, which are previously evaluated and have the following conditions: \\
i. High cultural heritage value \\
ii. Fragile or poor physical/chemical condition \\
iii. High use or demand \\
iv. High research interest \\
c) Collecting, compiling, and reproducing iconographic materials through \\
specific programs that create new sources for research. \\
d) Integrating digital born images through the institution's recording \\
activities. \\
(1.2 Geographic extent: \\
All photographic materials such as negatives and prints of historic, aesthetic or \\
technical relevance produced in Chile or by Chilean photographers elsewhere. \\
Photogatives, paper prints, photographic albums, photomechanical prints, and \\
Photographic materials that reveal relevant aspects of Chile as well as Latin American \\
\hline 1.3 Language scope: \\
Not specified
\end{tabular}




\subsection{Selected format:}

All formats.

\section{Selection parameters Used:}

The following reference parameters are in use for the collecting selection:

1. Historic value (established by specialists) ${ }^{44}$

2. Aesthetic value (established by specialists)

3. Research value (demanded by users)

\section{Forms of acquisition:}

1. Own production (Memoria Chilena, reproduction services, activities records archive)

2. Collection purchase (annual budget assigned by an acquisitions committee)

3. Donation reception (through public campaigns)

${ }^{44}$ The NL has a general acquisitions committee, formed by a group of senior librarians; however before presenting a proposal, there are a few photo historians connected with the NL who we seek advice from. 


\section{APPENDIX 4: SURVEY RESULTS}

\section{Introduction}

There is little information available in the consulted resources about photography collections policies for libraries. In an attempt to gain direct access to institutional collecting policies to complement the bibliographic research of my thesis work, and to create a general review of institutional policies, I designed a survey to gather knowledge of collecting policies already employed by selected institutions in Chile, as well as other institutions located throughout South and North America, Oceania and Europe.

In order to augment the information gathered by the survey, I first consulted the websites of those institutions similar to the National Library of Chile where I found a substantial amount of useful information on the collecting policies of these institutions.

The written survey was sent to thirteen photographic collections managers at the selected Chilean institutions, as well as to five national libraries in Latin America and five from elsewhere in the world. The selection criteria were based on a preliminary review of the photography collections and the similarity of the institutional context with the National Library of Chile case study. Eight responses were received, which will be discussed later in this Appendix.

The survey gathered useful information from the respondent institutions about the wide range of experiences they have had creating and implementing their collection policies. In addition to gaining insight into the collections policies of the selected 
institutions, I created valuable new contacts with collections managers of institutions with whom I can exchange more information in the future.

\section{Selected Institutions}

a. National Archives Chile

b. National Historical Museum Chile

c. National Library of Chile

d. National Library of Peru

e. National Library of Argentina

f. National Library of Colombia

g. National Library of Venezuela

h. Montevideo City Hall Photographic Centre

i. National Library of Australia

j. National Library of New Zealand

k. National Library of Spain

1. Library and Archives Canada

m. US Library of Congress

\section{Instruments}

\subsection{Letter and questionnaire}

The following letter was sent via e-mail to the selected institutions on two different dates, June $1^{\text {st }}$ and July $30^{\text {th }}, 2008$. The Spanish-language version has been translated by the author and has not been included in this document. 
To whom it may concern:

My name is Soledad Abarca and I am the Head of Photographic and Digital Archives of the National Library of Chile. I am contacting you because I am working on defining the collections policy for the department, and I would like to learn about the experience of your institution about this matter to gather important ideas and feedback.

This subject is also my thesis work to obtain my Masters Degree on Photographic Preservation and Collections Management at Ryerson University and George Eastman House.

As I mentioned before, I have done some previous research about policies for photographic archives within libraries, and I found that your Library has some information published online and I would like to have some extra information to include it into my work.

I would like to ask you to answer these brief survey questions:

\begin{tabular}{|l|l|l|}
\hline \multicolumn{2}{|l|}{ Identification: } \\
Contact: \\
\hline 1. Has your Photographic Collection/Archive written collections policies? & Yes & No \\
\hline 2. Is it a public document? & Yes & No \\
\hline 3. How long have these collections policies existed in your institution? & \\
\hline 4. Do you have complementary established protocols and regulations associated with the \\
policies?
\end{tabular}


6. Which are the most problematic aspects of applying the written policy?

7. How often do you review and update your policy?

8. Do you have a special working group for working on policies in your institution?

9. If your answer to question 1 was No, please explain why and how the lack of written policy has affected the collection management, and if you have any thoughts about this topic.

10. Other Comments:

I would really appreciate receiving some information from you. Thank you in advance,

Best regards,

Soledad Abarca de la Fuente

Archivo Fotográfico y Digital

Biblioteca Nacional de Chile

(56 2) $3605285-3695406$

http://www.dibam.cl/biblioteca nacional 


\subsection{Analysis}

Most of the thirteen institutions selected were national libraries, however, some museums and archives were included because of the nature of their photographic collections.

\begin{tabular}{|l|l|l|l|}
\hline Identification & URL & Have policy? & $\begin{array}{l}\text { Is it available } \\
\text { online? }\end{array}$ \\
\hline $\begin{array}{l}\text { National Archives } \\
\text { Chile }\end{array}$ & $\underline{\text { http://www.dibam.cl/archivo_nacional/ }}$ & no & no \\
\hline $\begin{array}{l}\text { National Historical } \\
\text { Museum Chile }\end{array}$ & $\underline{\text { http://www.dibam.cl/historico_nacional/ }}$ & yes & yes \\
\hline $\begin{array}{l}\text { National Library of } \\
\text { Chile }\end{array}$ & $\underline{\text { http://www.dibam.cl/biblioteca_nacional// }}$ & yes & no \\
\hline $\begin{array}{l}\text { National Library of } \\
\text { Peru }\end{array}$ & $\underline{\text { http://www.bnp.gob.pe/ }}$ & no & no \\
\hline $\begin{array}{l}\text { National Library of } \\
\text { Argentina }\end{array}$ & $\underline{\text { http://www.bn.gov.ar/ }}$ & yes & yes \\
\hline $\begin{array}{l}\text { National Library of } \\
\text { Colombia }\end{array}$ & $\underline{\text { http://www.bibliotecanacional.gov.co/ }}$ & yes & yes \\
\hline $\begin{array}{l}\text { National Library of } \\
\text { Venezuela }\end{array}$ & $\underline{\text { http://www.bnv.bib.ve/ }}$ & yes & yes \\
\hline $\begin{array}{l}\text { Montevideo City Hall } \\
\text { Photographic Centre }\end{array}$ & $\underline{\text { http://www.montevideo.gub.uy/ }}$ & yes & yes \\
\hline $\begin{array}{l}\text { National Library of } \\
\text { Australia }\end{array}$ & $\underline{\text { http://www.nla.gov.au/ }}$ & yes & yes \\
\hline $\begin{array}{l}\text { National Library of } \\
\text { New Zealand }\end{array}$ & $\underline{\text { http://www.natlib.govt.nz/ }}$ & yes & yes \\
\hline $\begin{array}{l}\text { National Library of } \\
\text { Spain }\end{array}$ & $\underline{\text { www.bne.es }}$ & yes & yes \\
\hline $\begin{array}{l}\text { Library and Archives } \\
\text { Canada }\end{array}$ & $\underline{\text { http://www.collectionscanada.gc.ca/ }}$ & yes & yes \\
\hline US Library of Congress & $\underline{\text { http://www.loc.gov/rr/print/ }}$ & yes & yes \\
\hline
\end{tabular}

Figure 1. Survey and Website

Figure 1 shows the results of the survey and website search. It lists each of the institutions selected, their URL address, whether or not they have a collections policy, and if their policy is available online. It is interesting to observe that most of the Englishspeaking institutions have their policies available online. On the contrary, most of the Spanish-speaking Latin American institutions do not have written policies, or these policies 
are "works in progress;" for example, Montevideo City Hall Photographic Centre in Uruguay, National Library of Colombia, and the case of study, the National Library of Chile. A detailed and translated record of the survey results is available later in this document. The institutional responses were entered into an Excel spreadsheet in order to create graphs and to tabulate and compare results.

\section{a. Website search results:}

Most institutions have some information about their collecting and collections development available on their websites. Some of them present the entire document in a PDF, which shows great transparency in the eyes of the public. There is an increasing trend in the digital age toward providing technical information online, giving the public remote access to collections.

The following pie charts show: the percentage of institutions with written policies (Figure 2); and the percentage of institutions with policies published online (Figure 3).

\section{Is there a policy?}

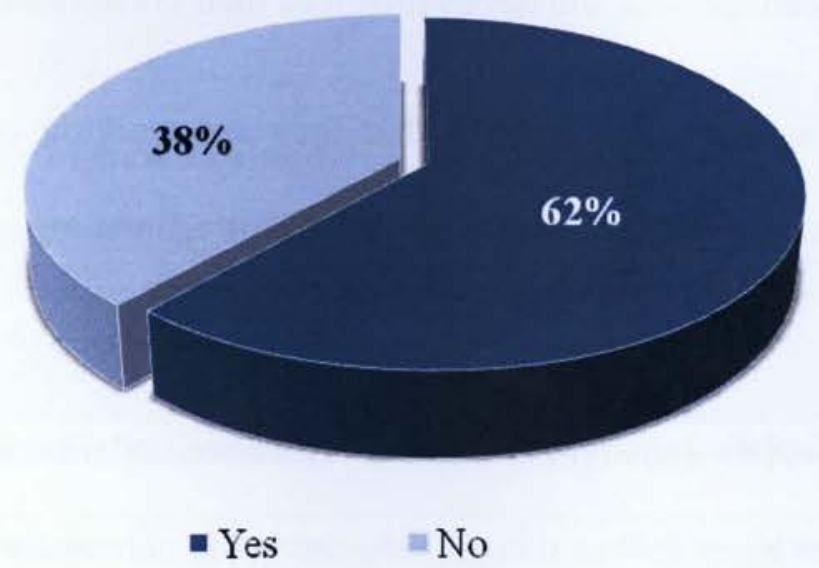

Figure 2. Percentage of institutions with written 


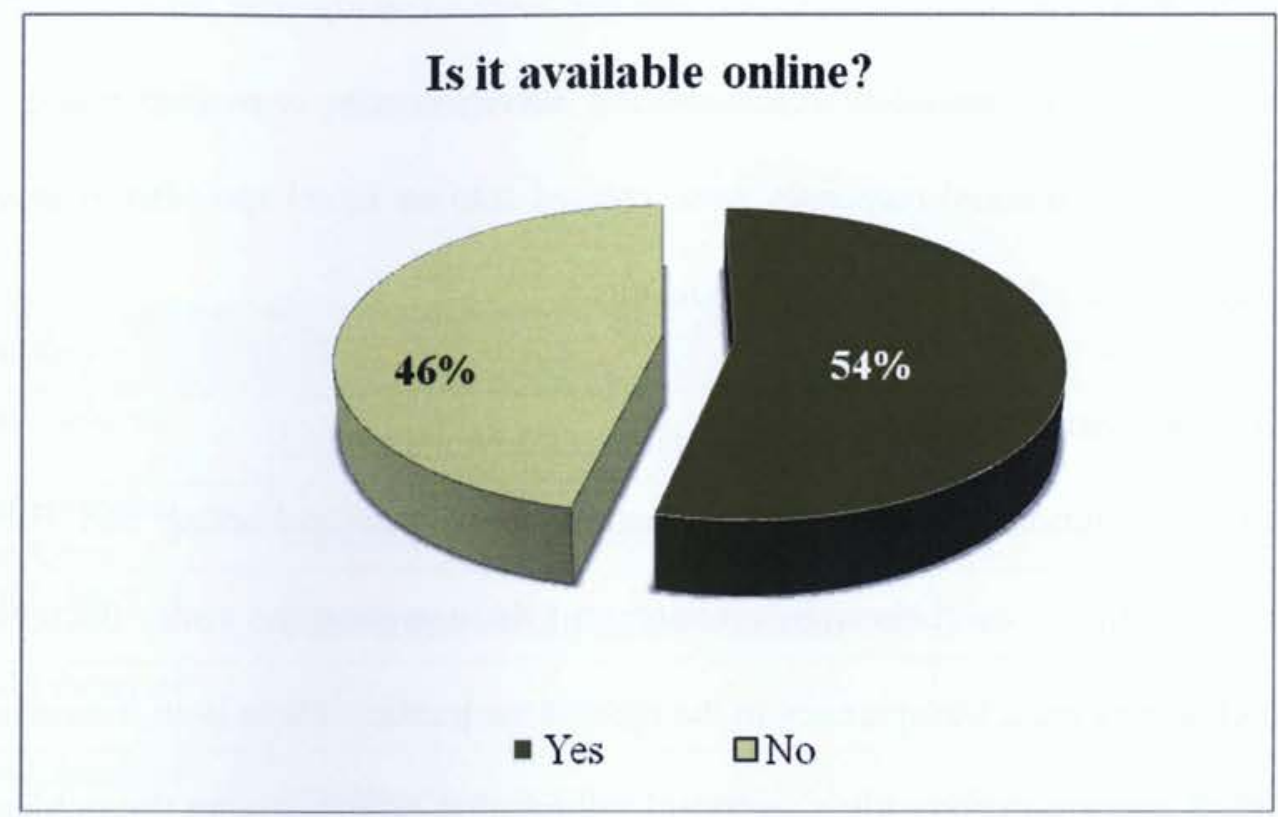

Figure 3. Percentage of institutions with written policies published

\section{b. The Written Survey:}

Eight institutions answered the written survey and, as can be seen in Figure 4, only $23 \%$ of the respondent institutions have written collections policies for their photography collections. Nevertheless, some of the institutions have general policies that provide overall guidelines for the management and development of their collections.

Some of the institutions replied that they are working on their policies, which reveals the recognition of the need for clear collections management activities and procedures.

The survey process showed that there is resistance towards discussion of this subject: some collection managers feel as though they are being personally scrutinized when asked about their institution's policies; coincidentally these were the institutions for which I 
couldn't find any information about policies online. This situation might be a contributing factor in the failure of $38 \%$ of the institutions to respond to the survey. Conversely, all the institutions with published policies answered very promptly, including the National Library of New Zealand and the United States Library of Congress.

\section{Written Survey results: Have policy?}

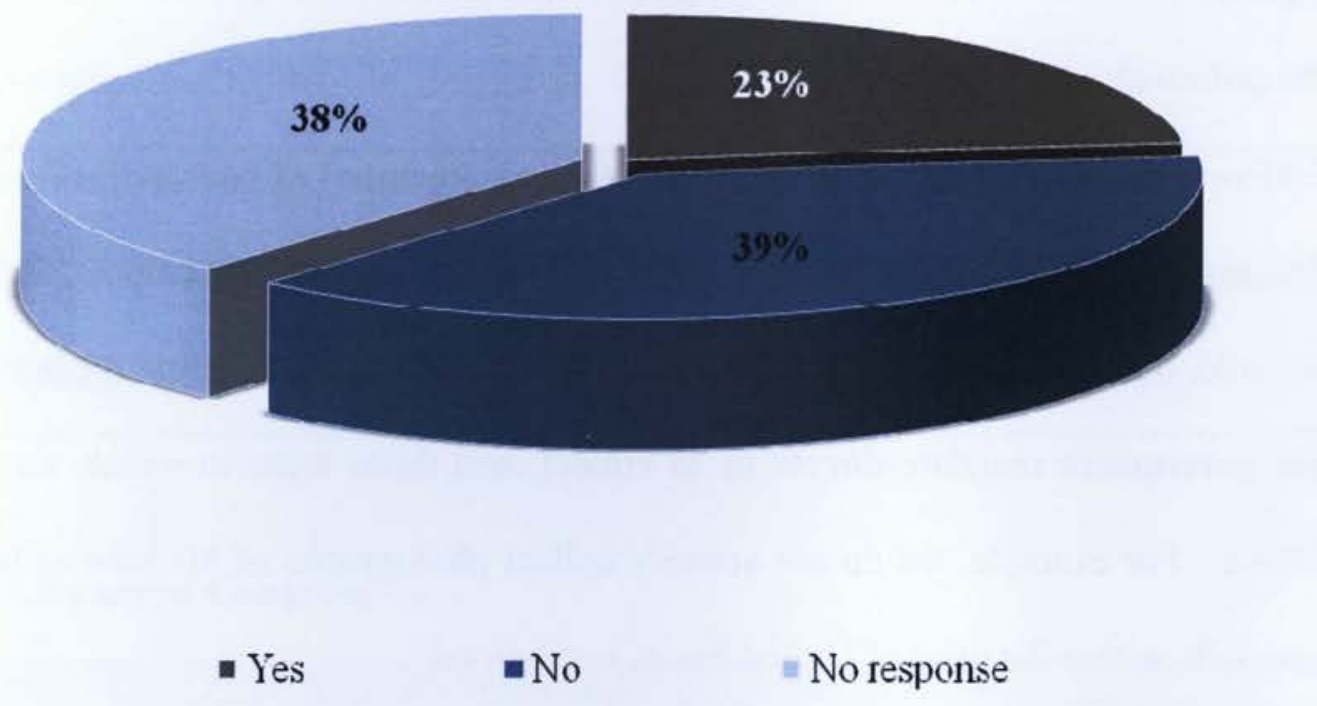

Figure 4. Percentage of Institutions with Written Collections

\section{c. Responses}

\section{- National Library of New Zealand}

\begin{tabular}{|c|c|c|c|}
\hline Identification: & \multicolumn{3}{|l|}{ Photographic Archive of The Alexander Turnbull Library } \\
\hline Contact: & \multicolumn{3}{|l|}{ John Sullivan, Curator } \\
\hline \multicolumn{2}{|c|}{ 1. Has your Photographic Collection/Archive written collections policies? } & $\underline{\text { Yes }}$ & No \\
\hline 2. Is it a pul & document? Photographic Archive of the Alex & $\underline{\text { Yes }}$ & No \\
\hline
\end{tabular}


Turnbull Library does have a written collections policy. It forms part of the Library's general collections policy and is a public document. It can be seen at:http://www.natlib.govt.nz/about-us/policies-strategy/our-policy-about-collections

\section{How long have these collections policies existed in your institution?}

The Alexander Turnbull Library has had a written collection policy since 1966, and a policy directed specifically at photographs was first formulated in the $1980 \mathrm{~s}$.

4. Do you have complementary established protocols and regulations associated with the policies?

\section{How has this policy been helpful with the management of your collection?}

The act of formulating a collection policy has been most useful in helping us to focus on our role, our responsibilities and our clients. It has forced us to define the areas in which our government mandate directs us to collect, and those areas in which we should not collect. For example, we do not actively collect photographs of Micronesia because this area falls within the orbit of United States institutions.

Having a written policy has also helped us to say no to people who wish to impose on us material which is not appropriate to our institution.

\section{Which are the most problematic aspects of applying the written policy?}

The most problematic aspects of applying the written policy are when dealing with material with a wide range of subject matter, some in scope and some not. We are sometimes offered photograph albums compiled by 19th Century world travelers, which contain a small number of New Zealand and Pacific photographs interspersed with those from other parts of the world. In such cases our decision is based on the uniqueness of the New Zealand photographs. 
7. How often do you review and update your policy? We have no set period for reviewing the policy, but would look at it, on average, once every 10 years.

8. Do you have a special working group for writing policies in your institution?

We do have a policy unit in the National Library of New Zealand, but individual curators will be expected to contribute on their areas of responsibility.

9. If your answer to question 1 was No, please explain why and how the lack of written policy has affected the collection management, and if you have any thoughts about this topic.

10. Other Comments: I hope that this helps. Please contact me if you require any further information. Visit our pictorial website http://timeframes.natlib.govt.nz/ and our catalogue http://tapuhi.natlib.govt.nz/SPYDB.HTM

- US Library of Congress

Identification: Library of Congress Prints and Photographs Division

Contact: $\quad$ Carol Johnson, Curator of Photography

\begin{tabular}{|l|l|l|}
\hline 1. Has your Photographic Collection/Archive written collections policies? & $\underline{\text { Yes }}$ & No \\
\hline $\begin{array}{l}\text { 2. Is it a public document? } \\
\text { We also have a longer document for internal use only. }\end{array}$ & $\underline{\text { Nes }}$ & \\
\hline
\end{tabular}

3. How long have these collections policies existed in your institution? Many years.

4. Do you have complementary established protocols and regulations associated with the policies? Yes. 


\begin{tabular}{l} 
5. How has this policy been helpful with the management of your collection? \\
It is an especially useful tool to use when we are evaluating unsolicited acquisitions. \\
6. Which are the most problematic aspects of applying the written policy? \\
doesn't fit within our policy, but would be important to acquire. Also with photography \\
changing from film to digital, I think we may update the policy again once we have more \\
experience with digital media. \\
\hline 7. How often do you review and update your policy? We are in the process of updating it \\
now. It's been about 15 years since we updated the policy. \\
\hline 8. Do you have a special working group for writing policies in your institution? \\
Yes. \\
9. If your answer to question 1 was No, please explain why and how the lack of written \\
this topic. \\
\hline 10. Other Comments:
\end{tabular}

\section{- Library and Archives Canada}

\begin{tabular}{|ll|l|l|}
\hline $\begin{array}{l}\text { Identification: } \\
\text { Contact: }\end{array}$ & Library and Archives Canada \\
& Jim Burant, Chief, Art and Photo Archives/chef des archives en art et de \\
& la Photographie \\
\hline $\begin{array}{l}\text { 1. Has your Photographic Collection/Archive written collections policies? } \\
\text { Yes, within the framework of a larger LAC Collections Development }\end{array}$ & & \\
\hline
\end{tabular}


Framework, we have a Private Sector Acquisition Orientation which is reviewed every five years, as well as more specific section acquisition policies and procedures, and a very specific photo acquisition strategy.

\section{How long have these collections policies existed in your institution?}

Generally speaking, the modern history dates back to 1967 , although I have been personally involved in such policy formulation since the late $1980 \mathrm{~s}$, after the proclamation of the National Archives Act in 1987, which lead to a 1988 Acquisition Policy, and a review of all Acquisition policies and procedures in 1989-1990. Since then, severe government restraint, various internal reorganizations, and the merger of the National Archives and National Library have affected the state of such policies.

\section{Do you have complementary established protocols and regulations associated with} the policies? Yes, we have appraisal criteria and selection guidelines which assist us in our work. See the attached documents.

\section{How has this policy been helpful with the management of your collection? Our} policies and procedures enable us to respond more quickly to acquisition offers made, most often in stating that materials do not fit into our policy or procedures or appraisal criteria. They also enable us to delineate our interests with regards to other institutions provincial, municipal, regional, university archives, museums and galleries, and other heritage bodies. This is a quick answer but you may want to ask me more questions in detail later on.

\section{Which are the most problematic aspects of applying the written policy?}

Of course there are many issues surrounding all of our policies, particularly in terms of definitions, vague descriptions of content, etc. What is the "documentary heritage" of 
Canada? Within the institution there are overlapping boundaries between various collecting areas - for example the Portrait Gallery of Canada (which is part of LAC) and the Canadian Archives and Special Collections Branch, between CASCB and the Government Records Branch, etc. And we could decide that we wanted to acquire a great deal but are too often prevented from doing so by lack of funds to purchase, lack of staff to appraise, acquire, arrange, and describe in order to make accessible, etc. And of course political and bureaucratic pressure is often brought to bear to acquire collections which may not at first glance be appropriate for the institution

7. How often do you review and update your policy? We tend to do it on a five-year cycle as you can tell from the documents I am supplying you, although the various Acquisition Committees at the department, branch, and section level often meet to discuss "exceptions" or "omissions" from the official document, for example, in responding to such priorities as aboriginal, multicultural, and digital records.

\section{Do you have a special working group for writing policies in your institution?}

There is actually a Strategic Office which is responsible for examining at a higher level all policies. The institution has a Major Acquisition Committee, at the Branch level there is a committee of the whole which considers acquisition policy on a more concrete level, and at the section level there is a Photo Acquisition Committee.

9. If your answer to question 1 was No, please explain why and how the lack of written policy has affected the collection management, and if you have any thoughts about this topic.

10. Other Comments: We create specific brochures to target certain kinds of 
photographic communities (see attached documents) as well as to explain the donation process. We attend various photographic organization conferences to spread the word about our collecting policies and interests. These include professional photojournalism communities (see http://www.ecnpa.com// and http://www.npac.ca/ as well as http://www.contactphoto.com/).

- National Library of Colombia

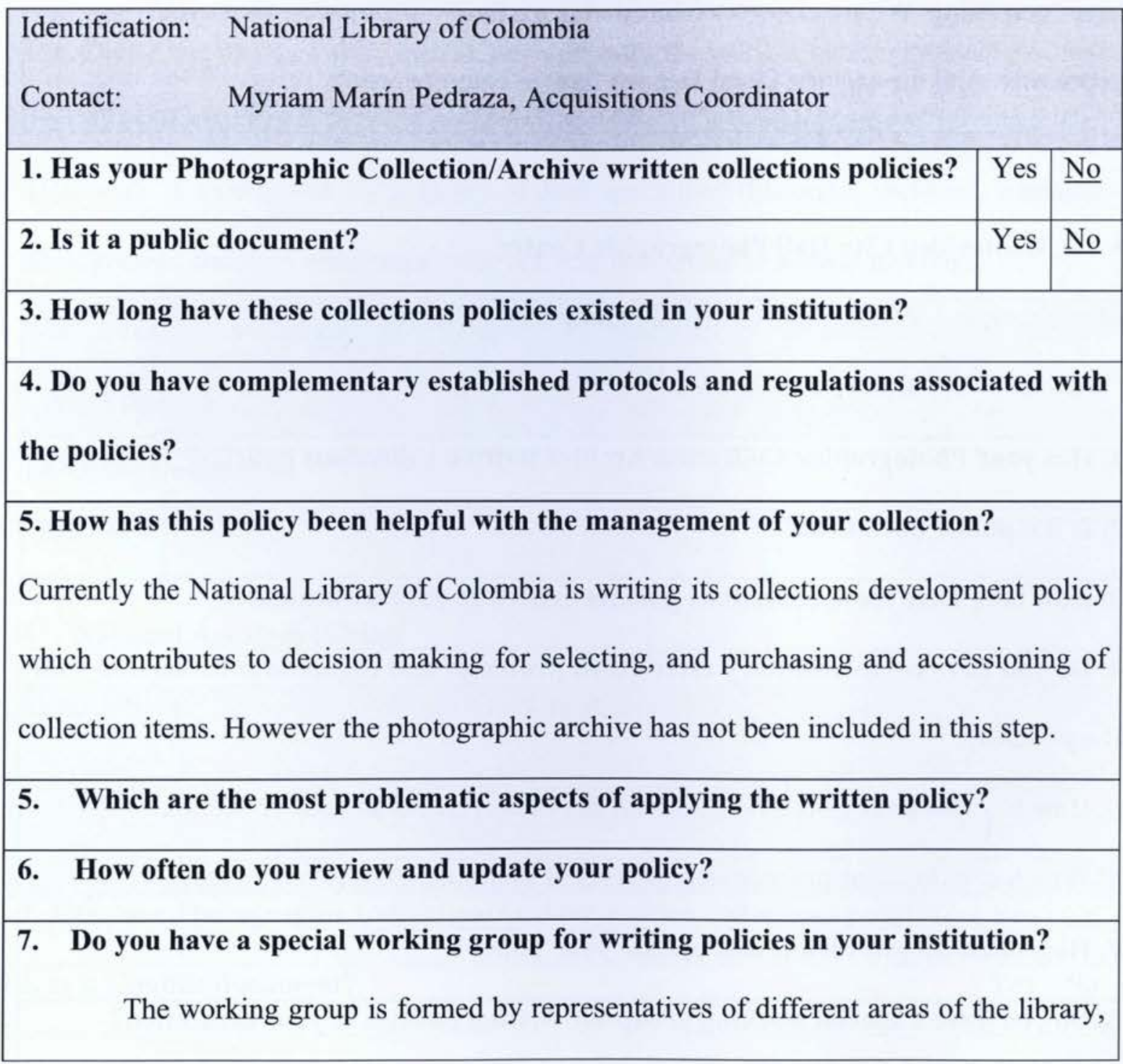


who are involved directly with collections management and services inside the institution.

8. If your answer to question 1 was $\mathrm{No}$, please explain why and how the lack of written policy has affected the collection management, and if you have any thoughts about this topic. The Library has begun writing the policies but the photographic archive is still waiting to be part of it.

9. Other Comments: Dear Soledad, I would like to ask you if the National Library in Chile has its own policy which you could share with us to help us on the work that we have been doing. We are also very interested to exchange information about your experience with the existing Legal Deposit Law in your country.

- Montevideo City Hall Photographic Centre

\begin{tabular}{ll}
\hline Identification: & Montevideo City Hall Photographic Centre \\
Contact: & Daniel Sosa, Director
\end{tabular}

\begin{tabular}{|l|l|l|}
\hline 1. Has your Photographic Collection/Archive written collections policies? & Yes & $\underline{\text { No }}$ \\
\hline 2. Is it a public document? & Yes & $\underline{\text { No }}$ \\
\hline
\end{tabular}

3. How long have these collections policies existed in your institution?

4. Do you have complementary established protocols and regulations associated with the policies?

5. How has this policy been helpful with the management of your collection?

6. Which are the most problematic aspects of applying the written policy?

7. How often do you review and update your policy?

8. Do you have a special working group for writing policies in your institution? 
9. If your answer to question 1 was No, please explain why and how the lack of written policy has affected the collection management, and if you have any thoughts about this topic. The City Hall Photographic Center was created 5 years ago, based on the Press Service collections which were in existence for over eighty years. The initial work has been carried out with intuition with a basic training and information available, but over time and with exchanges with other institutions, many advances have been accomplished by this institution. Internet and the support of many specialists of the region as well as the existing bibliography have helped the staff of the Center in this task.

The Center has its mission statement, and currently the work is concentrated to establish the ISO 9001 standard to create a set of protocols for all procedures.

This work is carried out by a group of five specialists (historian, archivist, manager, photographer and the Coordinator) who actively participate in weekly meetings.

Written policies are the final goal of this work which will be the result of a well planned thought process.

\section{Other Comments:}

- National Archives (Chile)

\begin{tabular}{|c|c|c|c|}
\hline Identification: & \multicolumn{3}{|l|}{ National Archives of Administration } \\
\hline Contact: & \multicolumn{3}{|c|}{ Roberto Aguirre, Conservation Coordinator of the National System of } \\
\hline & \multicolumn{3}{|l|}{ Archives } \\
\hline \multicolumn{2}{|c|}{ 1. Has your Photographic Collection/Archive written collections policies? } & Yes & No \\
\hline \multicolumn{2}{|c|}{ 2. Is it a public document? } & Yes & No \\
\hline
\end{tabular}




\section{How long have these collections policies existed in your institution?}

They have been not developed yet.

4. Do you have complementary established protocols and regulations associated with the policies? No.

\section{How has this policy been helpful with the management of your collection?}

We don't have special policies for photographic materials.

\section{Which are the most problematic aspects of applying the written policy?}

There are no written policies; however, there have been donations and acquisitions via legal transfer.

How often do you review and update your policy?

Never.

8. Do you have a special working group for working on policies in your institution? Yes, but there is a working group for the general policies of the Archives, although photographic archive has not been included.

9. If your answer to question 1 was No, please explain why and how the lack of written policy has affected the collection management, and if you have any thoughts about this topic. Our institution has two important photographic fonds, however, they have not been legally established as part of the National Archives property, and its administration and care are under the responsibility of the Conservation and Restoration Department.

10. Other Comments: The photographic fonds of the National Archives have over 100,000 materials, which represent a minor percentage of the immense amount of documents preserved in the Archives. In 1997 a project was developed to organize and 
describe the photographic material, which was stopped until last year.

- National Historical Museum (Chile)

\begin{tabular}{ll}
\hline Identification: & Archivo Fotográfico Museo Histórico Nacional \\
Contact: & Francisca Riera, Curator
\end{tabular}

\begin{tabular}{|l|l|l|l}
\hline 1. Has your Photographic Collection/Archive written collections policies? & $\underline{\text { Yes }}$ & No
\end{tabular}

Not particularly; however, the Museum has general guidelines established in the General Policies of the institution. I believe there is a need for developing policies for each collection within the museum because they are very different from each other and have specific requirements.

2. Is it a public document? General policies of the museum are available on paper as well as on the website publications section: http://www.dibam.cl/historico nacional.

3. How long have these collections policies existed in your institution?

General policies were developed in 2005.

4. Do you have complementary established protocols and regulations associated with the policies? They are not completely developed, because it depends on the Directorate of Museums. The Museum has its own procedure for the purchase and use of images of the Photo Archive, but it is very broad and basic.

\section{How has this policy been helpful with the management of your collection?}

The general policy establishes limits for the management of collections regarding acquisitions. It also specifies responsibilities of the staff with collections, including rights and duties. 


\section{Which are the most problematic aspects of applying the written policy?}

One of the main problems is that there is an overall lack of knowledge of the general policies among the museum staff. Another problem is the lack of written specific rules and procedures which is still a work in progress.

7. How often do you review and update your policy? The general policy is quite a new document; however, it is being reviewed constantly as new situations develop in the institution.

8. Do you have a special working group for writing policies in your institution?

Yes, the Heritage Department, which is formed by each collection's curators, the conservator and the registrar of the Museum.

9. If your answer to question 1 was No, please explain why and how the lack of written policy has affected the collection management, and if you have any thoughts about this topic.

\section{Other Comments:}

- National Library of Chile

$\begin{array}{ll}\text { Identification: } & \text { National Library of Chile } \\ \text { Contact: } & \text { Marjorie Peña, Head of Collections }\end{array}$

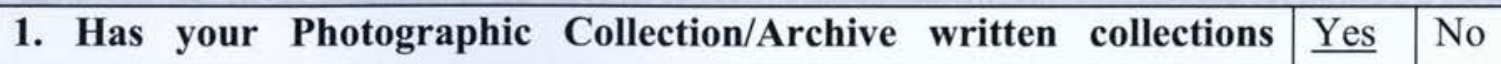
policies? NL has general collections development policy.

2. Is it a public document?

3. How long have these collections policies existed in your institution? 
These policies were developed by a working group in 1988 and they were unofficially used from 1999, even though they were never approved by the Director.

4. Do you have complementary established protocols and regulations associated with the policies? Yes.

\section{How has this policy been helpful with the management of your collection?}

The policy has contributed to the selection and acquisition process of new materials for the NL, as well as for donations and transfers. It has been helpful to set the priorities and scope of collections as well as to maintain continuity on the processes.

\section{Which are the most problematic aspects of applying the written policy?}

Special collections are the most problematic departments in policymaking because of the complexity of their collections.

\section{How often do you review and update your policy?}

They were reviewed in 2006/2007.

8. Do you have a special working group for working on policies in your institution? No.

9. If your answer to question 1 was No, please explain why and how the lack of written policy has affected the collection management, and if you have any thoughts about this topic.

10. Other Comments: It is mandatory that these policies get the Director's approval to be disseminated throughout the institution and to be applied. It is also necessary to include updated information in the policy such as new technologies, and to reflect changes in the public in the global world. 


\section{APPENDIX 5: QUICK COLLECTING GUIDE FOR CHILEAN PHOTOGRAPHY OF TH 20TH CENTURY}

\section{Introduction}

The history of photography in Chile is in the early stages of development. However, since the beginning of the 21 st century, more historians have been publishing monographic studies of Chilean photographers, and a few of them are focused on specific periods of time, regions, and styles of photography.

One of the PDA objectives is to create a representative collection of the history of the media in Chile to serve as a resource for photo historians and researchers of other fields to configure the identity of the country as well as to identify its place within Latin America.

The main goal of this quick reference guide for Chilean photography of the $20^{\text {th }}$ century is to create a guide for curators to facilitate the process of acquisitions. It has been divided by decades, listing the photographers with work significant to the PDA because of their thematic and artistic influence. This guide will be updated and completed as more names are encountered in the future.

\section{- 1900-1920: Illustrated magazine photographers}

Obder Heffer - Documentary photographer, landscape and urban views, 1891-1900 Antonio Olivares Valdivia - Portraitist and event photographer, 1900-1940

\section{- 1920-1940: The local avant garde}

Rolando Calderón - Portraitist, 1900-1950

Enrique Mora - Postcard editor, landscapes, urban views, 1930-1960 
Tito Vásquez - Portraitist, 1918

Enrique Alonso - 1927

Gertrudis de Moses - Experimental photographer, portraitist 1901-1997

\section{- 1940-1960: Times of change}

Armando Sills - Portraitist, 1930-1969

Juan Gallardo - Portraitist, 1930-1950

Iván Csillag - Commercial photographer, industry, portraits, landscapes, 1945-1976

Raúl Alvarez - Portraitist, Fotocine Club, 1954-1975

Marcos Chamudes- Documentary photographer, 1907-1989

- 1960-1980: The social revolution

Sergio Larraín - Documentary photographer, Magnum photographer, 1934

Samuel Rojas - Commercial fashion and industrial photographer

Bob Borowic - Artist, photographer, portraitist, 1922

Samuel Mena - Documentary photographer, 1946

Juan Enrique Lira - Landscape photographer, 1927

Luis Poirot - Portraitist, 1940

Pedro Sánchez - Commercial photographer, portraitist, 1945

Antonio Larrea- Documentary photographer

- 1980-2000: The transition to democracy

Luis Weinstein - Documentary photographer, 1957

Paz Errázuriz - Documentary photographer, 1944 
Ilonka Csillag - Portraitist of writers, 1957

Oscar Wittke - Documentary photographer, 1957

Juan Domingo Marinello - Documentary photographer, 1948

George Munro - Documentary photographer, 1944

Ricardo Astorga - Documentary photographer, 1953

José Luis Granese - Documentary photographer, 1961

Helen Huges - Documentary photographer, 1948

Felipe Riobó - Documentary photographer, 1943

Alvaro Hoppe - Documentary photographer, 1956

Alejandro Hoppe - Documentary photographer 1961

Marco Ugarte - Documentary photographer, 1958

Claudio Perez - Documentary photographer, 1957

Hector Lopez - Documentary photographer, 1955

- 2000-2020: The new generations and the digital age

Andrés Figueroa - Landscape and portraits, 1974

Javier Godoy - Documentary photographer, 1965

Eduardo Núñez - Documentary photographer, 1952

Álvaro Larco - Documentary photographer, 1966

Rodrigo Gomez Rovira - Documentary photographer, 1968 
APPENDIX 6: OFFICIAL SPANISH INSTITUTIONAL NAMES LIST.

\begin{tabular}{|c|c|}
\hline Spanish official name & Author's translation \\
\hline a. Archivo Fotográfico y Digital (AFD) & Photographic and Digital Archives (PDA) \\
\hline b. Archivo Nacional de Chile & National Archives Chile \\
\hline $\begin{array}{l}\text { c. Asociación de Bibliotecas Nacional de } \\
\text { de Iberoamérica (ABINIA) }\end{array}$ & $\begin{array}{l}\text { Association of National Libraries of Iberia- } \\
\text { America (ABINIA) }\end{array}$ \\
\hline d. Biblioteca Nacional de Argentina & National Historical Museum Chile \\
\hline e. Biblioteca Nacional de Colombia & National Library of Colombia \\
\hline f. Biblioteca Nacional de Chile (BN) & National Library of Chile (NL) \\
\hline g. Biblioteca Nacional de España & National Library of Spain \\
\hline h. Biblioteca Nacional de Peru & National Library of Peru \\
\hline i. Biblioteca Nacional de Venezuela & National Library of Venezuela \\
\hline $\begin{array}{l}\text { j. Centro Municipal de Fotografía de } \\
\text { Montevideo }\end{array}$ & Montevideo City Hall Photographic Centre \\
\hline $\begin{array}{l}\text { k. Centro Nacional de Conservación y } \\
\text { Restauración }\end{array}$ & Conservation Centre \\
\hline $\begin{array}{l}\text { 1. Centro Nacional de Patrimonio } \\
\text { Fotográfico }\end{array}$ & National Centre of Photographic Heritage \\
\hline m. Consejo de Monumentos & Council of Monuments \\
\hline $\begin{array}{l}\text { n. Consejo Nacional de la Cultura y las } \\
\text { Artes }\end{array}$ & Culture and Arts Council \\
\hline o. Dirección de Bibliotecas, Archivos y & Directorate of Libraries, Archives and \\
\hline
\end{tabular}




\begin{tabular}{|l|l|}
\hline \multicolumn{1}{|c|}{ Museos (DIBAM) } & Museums. \\
\hline p. Instituto del Patrimonio & Heritage Institute \\
\hline q. Cineteca Nacional del Palacio de la & Film Archives of Palacio La Moneda \\
\hline r. Ley de depósito legal & \\
\hline s. Ministerio de Educación & Legal Deposit Law \\
\hline t. Oficina de Propiedad Intelectual & Ministry of Education \\
\hline u. Palacio Real de la Aduana & Royal Customs Palace \\
\hline
\end{tabular}




\section{BIBLIOGRAPHY}

Ambrose, Tim. Museum Basics. Edited by Crispin Paine. New York: ICOM in conjunction with Routledge, 1993.

American Association of Museums. Caring for Collections: Strategies for Conservation, Maintenance, and Documentation: A Report on an American Association of Museums Project. Washington, D.C.: American Association of Museums, 1995.

Besnier, Verónica, and Xavier Gómez, editors. Chile en 100 miradas. Santiago: Lom Ediciones, 2005

Buck, Rebecca A., and Jean Allman Gilmore, editors. The New Museum Registration Methods. Washington, DC: American Association of Museums, 1998.

Dirección de Bibliotecas Archivos y Museos. Biblioteca Nacional. Santiago: Ediciones de la Dirección de Bibliotecas Archivos y Museos, 1982.

Dirección de Bibliotecas Archivos y Museos. Bibliotecas de Chile. Santiago: Ediciones de la Dirección de Bibliotecas Archivos y Museos, 1985.

Ferrer, Rita. Yo Soy Fotografia. Santiago: Ediciones de la Hetera., 2002, 
Fahy, Anne ed. Collections Management. London: Routledge 1995

Granese, José, ed. Contemporary Chilean Photography, Santiago: Kodak, 1985

Lord, Barry, and Gail Dexter, editors. The Manual of Museum Exhibitions. Walnut Creek, CA: Alta Mira Press, 2002.

J. Paul Getty Museum, ed. The J. Paul Getty Museum Handbook of the Collections. Malibu, California, 1991.

Marie C. Malaro. Museum Governance: mission ethics, policy. Smithsonian Institution Press. Washington: 1994.

Moreno, Jose, and Denise Fresard editors. Antonio Quintana 1904-1972. Santiago: Fundación Centro Cultural Palacio La Moneda, 2006

Museo Nacional de Bellas Artes, ed. Exposición Fotográfica 70 años Foto Cine Club de Chile. Santiago: Ediciones de la Dirección de Bibliotecas Archivos y Museos, 2008.

Ross, Richard. Museology. Edited by David Mellor, Phyllis Plous and University of California, Santa Barbara.University Art Museum. New York: Aperture, in association with the University Art Museum, Santa Barbara, 1989. 
Ritzenthaler, Mary Lynn. Photographs: Archival Care and Management, edited by Diane Vogt-O'Connor, Mary Lynn Ritzenthaler. Chicago: Society of American Archivists, 2006 .

\section{Electronic Resources}

Aleph Integrated Library System, http://www.exlibrisgroup.com/category/Aleph (accessed July 15 th, 2008).

British Library. "Collections Development Policy.” British Library.

http://www.bl.uk/aboutus/stratpolprog/coldevpol/(accessed July 15th, 2008).

Collection Development Training for Arizona Public Libraries. "Collection Development Training." Arizona Public Libraries.. http://www.lib.az.us/cdt/(accessed July 15th, 2008).

Consejo Nacional de la Cultura y las Artes. "Chile quiere más Cultura, Definiciones de Política Cultural 2005-2010, Mayo 2005." Consejo Nacional de la Cultura y las Artes. http://cnca.q2.cl/archivos/20055/politicas2005.pdf(accessed July 15th, 2008).

Museo de Arte Contemporáneo. "Chile from within." Museo de Arte Contemporáneo. http://www.mac.uchile.cl/exposiciones/chilewithin/(accessed July 15th, 2008). 
Convención del consejo de la cultura y las artes 2006, "Intervención de Nivia Palma".

Dirección de Bibliotecas, Archivos y Museos.

http://www.dibam.cl/contenido.asp?id_contenido $=824 \&$ id_subsubmenu $=1126 \& i d \_s$ $\underline{\text { Mmenu}=1122 \& i d ~ m e n u=1}$ (accesed July 15 th, 2008).

Dirección de Bibliotecas, Archivos y Museos. "Memoria, cultura y creación. Lineamientos políticos, (2005)”. Dirección de Bibliotecas, Archivos y Museos. http://www.dibam.cl/contenido.asp?id_contenido=77\&id_subsubmenu=1123\&id_su bmenu=1122\&id_menu=1 (accessed July 15 th, 2008).

International Council of Museums. "Acquisitions code of ethics, 1970." http://icom.museum/acquisition.html (accessed July 15th, 2008).

International Federation of Library Associations and Institutions Section on Acquisition and Collection Development. "Guidelines for a collection development policy using the conspectus model. 2001." International Federation of Library Associations http://www.ifla.org/VII/s14/ndl/gcdp-e.pdf (accessed July 15th, 2008).

Library of Congress. "Collection Policy Statement." Library of Congress. http://www.loc.gov/acq/devpol/photogra.html (accessed July 15th, 2008). 
Ministerio Secretaria General de Gobierno. "Extractos de la ley 19.733 sobre las libertades de opinión e información y ejercicio del periodismo.” Gobierno de Chile. http://www.dibam.cl/dinamicas/DocAdjunto_208.pdf (accessed July 15th, 2008).

Museo de Arte Virtual. http://www.mav.cl/fotografia.html (accessed July 15th, 2008).

Museo Histórico Nacional. "Política de Colecciones Museo Histórico Nacional." Museo Histórico Nacional. http://www.dibam.cl/dinamicas/DocAdjunto 97.pdf (accessed July 15 th, 2008).

National Archives of Canada, Preservation Policies, September, 2002. http://www.collectionscanada.ca/preservation/1304 e.html (accessed July 15th, 2008).

Trustee Resources. "Sample Public Library Policies \& Development Tips." Mid-Hudson Library System.

http://midhudson.org/department/member information/library policies.htm (accessed July 15th, 2008).

\section{Institutional websites}

American Library Association. http://www.ala.org/(accessed July 15th, 2008). 
Archivo Fotográfico del Museo Histórico Nacional Online Catalogue.

http://www.fotografiapatrimonial.cl/ (accessed July 15th, 2008).

Archivo Fotográfico de la Universidad de Concepción. http://www2.udec.cl/ fotoudec/ (accessed July 15th, 2008).

Asociación de Bibliotecas Nacionales de Iberoamérica (ABINIA). http://www.abinia.org/ (accessed July 15th, 2008).

Biblioteca Nacional de Argentina. http://www.bibnal.edu.ar (accessed July 15th, 2008).

Biblioteca Nacional de Chile. www.dibam.cl (accessed July 15th, 2008).

Biblioteca Nacional de Colombia. http://www.bibliotecanacional.gov.co/(accessed July 15th, 2008).

Biblioteca Nacional de España. http://www.bne.es (accessed July 15th, 2008).

Biblioteca Nacional del Perú. http://www.bnp.gob.pe/portalbnp/(accessed July 15th, 2008).

Biblioteca Nacional de Venezuela.

http://www.bnv.bib.ve/cole_obra plana.php?sw=4\&f=24 (accessed July 15th, 2008). 
Centro Municipal de Fotografía. http://www.montevideo.gub.uy/fotografia/(accessed July 15th, 2008).

Centro Nacional del Patrimonio Fotográfico. http://www.patrimoniofotografico.cl/ (accessed July 15th, 2008).

Council on Library and Information Resources (CLIR).

http://www.clir.org/about/about.html (accessed July 15th, 2008).

Dirección de Bibliotecas, Archivos y Museos, Chile. http://www.dibam.cl (accessed July 15th, 2008).

Library of Congress. http://www.loc.gov/index.html (accessed July 15th, 2008).

National Library of Australia. http://www.nla.gov.au/(accessed July 15th, 2008).

National Library of New Zealand. http://www.natlib.govt.nz/(accessed July 15th, 2008).

Northeast Document Conservation Center.

http://www.nedcc.org/resources/leaflets/1Planning_and_Prioritizing/05CollectionsPolicies. php (accessed July 15th, 2008). 